\title{
Potential Role of Lycopene in the Prevention of Postmenopausal Bone Loss: Evidence from Molecular to Clinical Studies
}

\author{
Umani S. Walallawita ${ }^{1}$, Frances M. Wolber ${ }^{1}$, Ayelet Ziv-Gal ${ }^{2} \mathbb{D}$, Marlena C. Kruger ${ }^{3}{ }^{(D)}$ and \\ Julian A. Heyes ${ }^{1, *}$ \\ 1 School of Food and Advanced Technology, Massey University, Palmerston North 4442, New Zealand; \\ u.walallawita@massey.ac.nz (U.S.W.); F.M.Wolber@massey.ac.nz (F.M.W.) \\ 2 College of Veterinary Medicine, University of Illinois at Urbana-Champaign, Urbana, IL 61802, USA; \\ zivgal1@illinois.edu \\ 3 School of Health Sciences, Massey University, Palmerston North 4442, New Zealand; \\ m.c.kruger@massey.ac.nz \\ * Correspondence: J.A.Heyes@massey.ac.nz; Tel.: +64-6-951-6323
}

Received: 29 August 2020; Accepted: 24 September 2020; Published: 27 September 2020

\begin{abstract}
Osteoporosis is a metabolic bone disease characterized by reduced bone mineral density, which affects the quality of life of the aging population. Furthermore, disruption of bone microarchitecture and the alteration of non-collagenous protein in bones lead to higher fracture risk. This is most common in postmenopausal women. Certain medications are being used for the treatment of osteoporosis; however, these may be accompanied by undesirable side effects. Phytochemicals from fruits and vegetables are a source of micronutrients for the maintenance of bone health. Among them, lycopene has recently been shown to have a potential protective effect against bone loss. Lycopene is a lipid-soluble carotenoid that exists in both all-trans and cis-configurations in nature. Tomato and tomato products are rich sources of lycopene. Several human epidemiological studies, supplemented by in vivo and in vitro studies, have shown decreased bone loss following the consumption of lycopene/tomato. However, there are still limited studies that have evaluated the effect of lycopene on the prevention of bone loss in postmenopausal women. Therefore, the aim of this review is to summarize the relevant literature on the potential impact of lycopene on postmenopausal bone loss with molecular and clinical evidence, including an overview of bone biology and the pathophysiology of osteoporosis.
\end{abstract}

Keywords: bone; osteoporosis; lycopene; tomato; postmenopause

\section{Introduction}

Osteoporosis is an age-related health problem which reduces the quality of life. It is estimated that over 200 million people suffer from osteoporosis worldwide [1]. Approximately $30 \%$ of postmenopausal women in Europe and the United States are affected by osteoporosis [2]. Based on the projected estimations, there will be a $32 \%$ increase in the incidence of osteoporosis and low bone mass in older adults (aged $\geq 50$ ) by 2030 [3]. Moreover, the cost of treatments for osteoporosis is rapidly increasing annually as the total number of fractures increases. Developing countries especially may face a huge economic burden due to more fragility fractures occurring with higher life expectancies and a growing elderly population $[4,5]$. The projected estimate of the increase in the incidence of hip fractures in women and men worldwide is $240 \%$ and $310 \%$, respectively, by 2050 .

The most prominent types of fractures occur at the sites of the hip, spine vertebrae, and distal forearm [4]. Complications of osteoporosis, such as hip fractures, lead to a four-times-higher mortality 
rate in the adult population worldwide [6]. In general, one in three women (50 years or older) may have osteoporotic fractures [7]. Osteoporosis can be categorized into two types: primary osteoporosis and secondary osteoporosis [8]. Primary osteoporosis can be further divided into postmenopausal osteoporosis (type 1) and senile osteoporosis (type 2) [9]. Postmenopausal osteoporosis is primarily caused by estrogen deficiency, which occurs in women after menopause, while senile osteoporosis gradually develops with aging ( $>70$ years old) in both sexes [10]. Secondary osteoporosis generally has a definable etiology such as malnutrition, chronic disease, endocrine dysfunction, medication side effects, or metastatic or hematological malignancy [8].

Diets rich in phytochemicals, particularly carotenoids from fruits and vegetables, have been found to be effective for the maintenance of bone mineral status [11,12]. Among them, the potential protective effects of lycopene against bone loss have been recently documented [13,14]. Lycopene is an acyclic carotenoid, containing 11 conjugated double bonds in the all-trans-isomeric form or various cis-configurations [15]. Compared to all-trans, cis-isomers are considered to be more bioavailable because they are highly soluble in lipid micelles, readily taken up by intestinal cells, less likely to crystalize, and they also preferentially bind to chylomicrons [16]. Thus, cis-isomers are more easily transported within cells, across the plasma membrane, and into the tissue matrix $[16,17]$.

Tomatoes and tomato-based products are rich sources of lycopene and represent more than $80 \%$ of human dietary sources containing lycopene. Depending on the variety of tomato, the average lycopene content lies between $0.7-20 \mathrm{mg} / 100 \mathrm{~g}$ fresh weight [18]. However, dietary sources of lycopene are primarily found in the all-trans-isomeric form. For example, red tomatoes contain almost $90 \%$ of their total lycopene in the all-trans-form [15], yet cis-lycopene concentrations in body tissues are higher than those of other lycopene isomers $[18,19]$. This could be due to isomerization occurring during food processing or post consumption during digestion and absorption. Although lycopene has beneficial effects on human health, there is a gap between dietary intake and the amount available for biological action in the body. Therefore, various food processing techniques (e.g., heat treatment) are used to improve the bio-accessibility of all-trans-lycopene. These processing techniques can disrupt the cell wall and release lycopene out of the cells. Additionally, since lycopene is fat-soluble, the incorporation of fat into the meal or red tomato product increases the bioavailability of lycopene. There are other natural sources of more bioavailable lycopene, such as orange heirloom tomatoes that contain $>90 \%$ of lycopene in the cis-isomeric form [20,21]. In these tomatoes, the carotenoid isomerase enzyme, which converts cis-lycopene to all-trans, is in a nonfunctional form; thus, they retain considerably higher amounts of cis-isomers and may be a better source of dietary lycopene for humans.

There is an emerging interest among researchers to study lycopene for the prevention of postmenopausal osteoporosis and to explore ways to improve lycopene bioavailability from natural sources such as tomatoes. The purpose of this review is to discuss the literature regarding the impact of lycopene on bone metabolism, including an investigation into natural sources of more bioavailable lycopene.

\section{Bone Biology, Modelling, and Remodeling}

Bone is a specialized connective tissue that is responsible for the framework of the body. Primarily, the skeleton provides support for the body and assists its movements. Bones also act as a major mineral reservoir, carrying $99 \%$ of calcium, $85 \%$ of phosphorus, and $65 \%$ of magnesium body stores, and they are the main repository of growth factors and cytokines [8]. Moreover, bone plays an important role in acid-base balance and hormonal functions related to phosphate metabolism, blood glucose, and fat deposition in the body [8]. Bone also helps in the detoxification of heavy metals and other waste materials by removing them from blood circulation $[8,22,23]$. Bone generally comprises three components: organic matrix, inorganic salts, and water. Approximately $90 \%$ of the organic matrix consists of collagenous protein, non-collagenous protein, and growth factors. The inorganic matrix contains mainly calcium and phosphorus in the form of hydroxyapatite crystals [24]. Depending on the degree of porosity, bones are categorized as cortical bone (compact) or trabecular bone (cancellous). 
Cortical bone is denser, while trabecular bone is more porous. The porosity of cortical bone is approximately $3-5 \%$ and may increase with age $[23,25]$. Cortical bones represent $80 \%$ of the adult skeleton. Trabecular bone is more metabolically active than cortical bone. This difference occurs due to the higher surface area of trabecular bone compared to cortical bone [23].

Bone tissue contains four different cell types: osteoblasts, osteoclasts, osteocytes, and bone lining cells. Osteoblasts originate from mesenchymal stem cells and are responsible for bone formation [26]. Osteoclasts are derived from mononuclear hematopoietic stem cells and are responsible for bone resorption [27]. The majority of mature osteoblasts may undergo apoptosis, while a minority re-differentiate into osteocytes or lining cells [28]. Approximately $90-95 \%$ of bone cells are osteocytes, which have a long life span of nearly 25 years [24,29]. Bone marrow, found in the bone cavity, consists of two types of cells: hematopoietic and stromal. Hematopoietic stem cells produce osteoclasts, immune cells, platelets, and red blood cells, while mesenchymal stem cells produce osteoblasts, cartilage, and adipocytes [27,29].

Bone tissue undergoes two major physiological processes: modeling and remodeling. Bone modeling is characterized by a change in the shape of the bone as a result of physiological influences or mechanical forces [30]. For example, bone modeling widens the bones with aging [8]. Moreover, bone modeling is upregulated in hypoparathyroidism, chronic kidney disease (CKD), and medical treatments containing anabolic agents [31]. During bone modeling, the changes in the shape of bones are regulated by independent actions of osteoblasts and osteoclasts [32].

In contrast, bone remodeling occurs throughout life and is responsible for the removal of older bone and its replacement with new bone structure $[8,33,34]$. Bone remodeling involves a sequence of cellular activities that occur within a specialized multicellular unit [35]. The bone multicellular unit is predominantly comprised of osteoclasts, osteoblasts, and osteocytes [24]. There are 3-4 million basic multicellular units (BMU) produced each year, and approximately one million among them actively participate in the bone remodeling process [36]. Bone remodeling has four major stages: activation, resorption, reversal, and formation [35]. In the first step, osteoblastic stromal cells or lining cells are activated via lining cell retraction and endosteal membrane digestion by collagenase. Following this, osteoclasts initiate bone resorption by dissolving the mineral matrix [8,35]. At the end of the resorption phase, mononuclear cells such as monocytes, osteocytes, and preosteoblasts are found in resorption cavities [8]. During the reversal phase, a cement lining rich in mucopolysaccharides is deposited between old and new bone, as well as signaling molecules that can activate osteoblast precursors. Therefore, the reversal phase is considered a transitional phase between resorption and formation of new bone [35]. Lastly, a new organic matrix is produced by osteoblasts, which eventually mineralizes into new bone [32]. The resorption and reversal phases last for 2 weeks and $4-5$ weeks, respectively. The formation phase is the longest and lasts approximately $4-6$ months until the new bone is completely formed $[30,37,38]$.

Approximately $90 \%$ of cortical bone is calcified; thus, it contains a low surface area to volume ratio. This leads to a slower rate of remodeling in cortical bone compared to trabecular bone [23]. Approximately $25 \%$ of the body's trabecular bone is remodeled each year compared to only $2.5 \%$ of cortical bone [23]. Bone remodeling is regulated by various systemic and local factors. Genetics, mechanical factors, vascular factors, nutrition, and hormones are considered systemic regulators, while growth factors, matrix proteins, and cytokines act as local regulators [8,24,35,37,39]. At menopause, bone remodeling increases and continues at a higher rate for 5-10 years due to the decrease in levels of estrogen [31].

\section{Postmenopausal Osteoporosis: A Silent Disease}

Postmenopausal osteoporosis is a common metabolic disease among older women ( $\geq 50$ years). It is characterized by reduced bone mineral density along with disruption of bone microarchitecture and alteration of non-collagenous protein in bone, which together lead to higher fracture risk [8]. This disease reduces women's overall quality of life by significantly increasing their rates of morbidity, disability, 
and mortality. Osteoporotic bone tends to be more fragile and easily fractured [40]. In general, one in eight people will experience a second fracture within a year after their first osteoporotic fracture [41].

Bone mineral density (BMD), bone mineral content (BMC), and the quantity and quality of bone are the distinguishing factors between people with osteoporotic versus healthy bones [42]. The risk of osteoporosis is primarily evaluated through bone mineral density, which is predominantly measured by dual-energy X-ray absorptiometry (DEXA) scanning [38]. Other methods include magnetic resonance imaging (MRI), ultrasound, and microcomputed tomography [42,43]. Bone density is a quantitative measure, but its limitation is that it does not measure bone quality [44]. Therefore, measurements of bone turnover markers as proxies for bone formation and bone resorption are used to evaluate the quality of bone in tandem with DEXA scanning [38].

For the diagnosis of osteoporosis, BMD values are converted into a T-score [2]. The T-score is calculated by dividing the difference between a female patient's BMD and the mean BMD of young, healthy women by the standard deviation of the reference population [2]. A T-score between -1 and $+1 \mathrm{SD}$ (standard deviation) is considered to be normal BMD. A T-score between -1 and $-2.5 \mathrm{SD}$ is categorized as osteopenia. A T-score of $-2.5 \mathrm{SD}$ is considered to be osteoporotic $[27,40,43,45,46]$. An imbalance between bone resorption and formation initially leads to osteopenia, which is characterized by low mineralization and is likely to further progress to osteoporosis [47]. The most common pharmacological treatments currently being used for osteopenia and osteoporosis are bisphosphonates, denosumab, anabolic agents, and hormone replacement therapy [41]. Most of these treatments have been shown to increase bone mass by up to $10 \%$ over 3-5 years [48]. Postmenopausal women are advised to take these medications with calcium and vitamin D supplements to increase their effectiveness [49].

\subsection{Risk Factors of Postmenopausal Osteoporosis}

Risk factors for osteoporosis can be primarily categorized as modifiable and nonmodifiable (Table 1). Heredity is the major nonmodifiable factor of osteoporosis, and children of parents with osteoporosis and fractures are themselves more prone to develop osteoporosis [50]. Osteoporosis is a polygenic disease that involves several genes. In rare instances, osteoporosis can be inherited due to mutations in single genes. Mutations of two genes of type 1 collagen (COL1A1 and COL1A2) are responsible for the dominant osteoporotic disease called "osteogenesis imperfecta", which is characterized by low bone mass and increased bone fragility [51-54]. Osteoporosis inheritance has also been linked with inactivating mutations in the aromatase (CYP19A1) and estrogen receptor alpha genes $(\mathrm{ER} \alpha)[55,56]$.

Table 1. Risk factors of postmenopausal osteoporosis.

\begin{tabular}{|c|c|}
\hline Fixed Risk Factors & Modifiable Risk Factors \\
\hline $\begin{array}{ll}\text { - } & \text { Menopause age [57] } \\
\text { - } & \text { Menopause and hysterectomy }[57,60] \\
\text { - } & \text { Estrogen deficiency and amenorrhea [62] } \\
\text { - } & \text { Family history of osteoporosis }[64,65] \\
\text { - } & \text { Previous fractures [67] } \\
\text { - } & \text { Height loss (>0.5 cm per year) [69] } \\
\text { - } & \text { Ethnicity (Caucasian and Asian population are at high risk) [72] }\end{array}$ & $\begin{array}{ll}\text { - } & \text { Inadequate calcium and vitamin D intake }[58,59] \\
\text { - } & \text { Alcohol consumption [61] } \\
\text { - } & \text { Cigarette smoking [63] } \\
\text { - } & \text { Eating disorders [68] } \\
\text { - } & \text { Inadequate physical exercise }[70,71] \\
\text { - } & \text { Frequent falls [73] }\end{array}$ \\
\hline
\end{tabular}

Estrogen deficiency is the primary risk factor of postmenopausal osteoporosis; other contributors besides the genetics mentioned above include modifiable factors such as nutrition, certain medications, and lifestyle (Table 1) [10,74]. Bone cells (osteoblast, osteoclast, and osteocytes) contain estrogen receptors on their surface [75]. Stimulation of estrogen receptors, particularly on osteoblasts, may inhibit the activation of osteoclasts and thus reduce bone resorption and protect bones from osteoporosis [76]. Oxidative-stress-generating factors such as poor nutrition, low antioxidants in the body, smoking, alcohol intake, and excessive caffeine intake can be modified through lifestyle 
changes $[6,40]$. For example, a diet low in calcium may induce secretion of parathyroid hormone, which activates osteoclasts and bone resorption [76].

Interestingly, some cross-sectional studies have found an inverse relationship between sleep duration and BMD in elderly women $[77,78]$. It has been hypothesized that a shorter waketime reduces the daily mechanical loading that induces bone remodeling, and thus reduces BMD [78]. Lower melatonin levels due to reduced light exposure may lead to fewer interactions between estrogen and its receptors and, thus, negatively impact BMD [79]. However, other studies report either positive or null relationships between sleep duration and BMD in postmenopausal women [80-83]. The conflicting evidence in this area may be due to confounding study participant factors that are not uniformly controlled for across the studies, such as age, body composition, diet, and nighttime-only sleep duration versus inclusion of daytime naps.

\subsection{Pathophysiology of Postmenopausal Osteoporosis}

The occurrence of postmenopausal osteoporosis is dependent mainly on body estrogen levels. Estrogen regulates bone turnover either by directly interfering with osteocytes and osteoclasts or by regulating T-lymphocyte function and the formation of osteoblasts [84]. Estrogen has both skeletal and non-skeletal functions, and, due to the former deficiencies, can cause bone-related diseases (Figure 1). Women are at higher risk 3-5 years after the onset of menopause [85]. The mechanism by which estrogen deficiency causes postmenopausal osteoporosis is complex. Estrogen can influence bone remodeling through inhibiting cell differentiation and increasing osteoclast apoptosis [85].

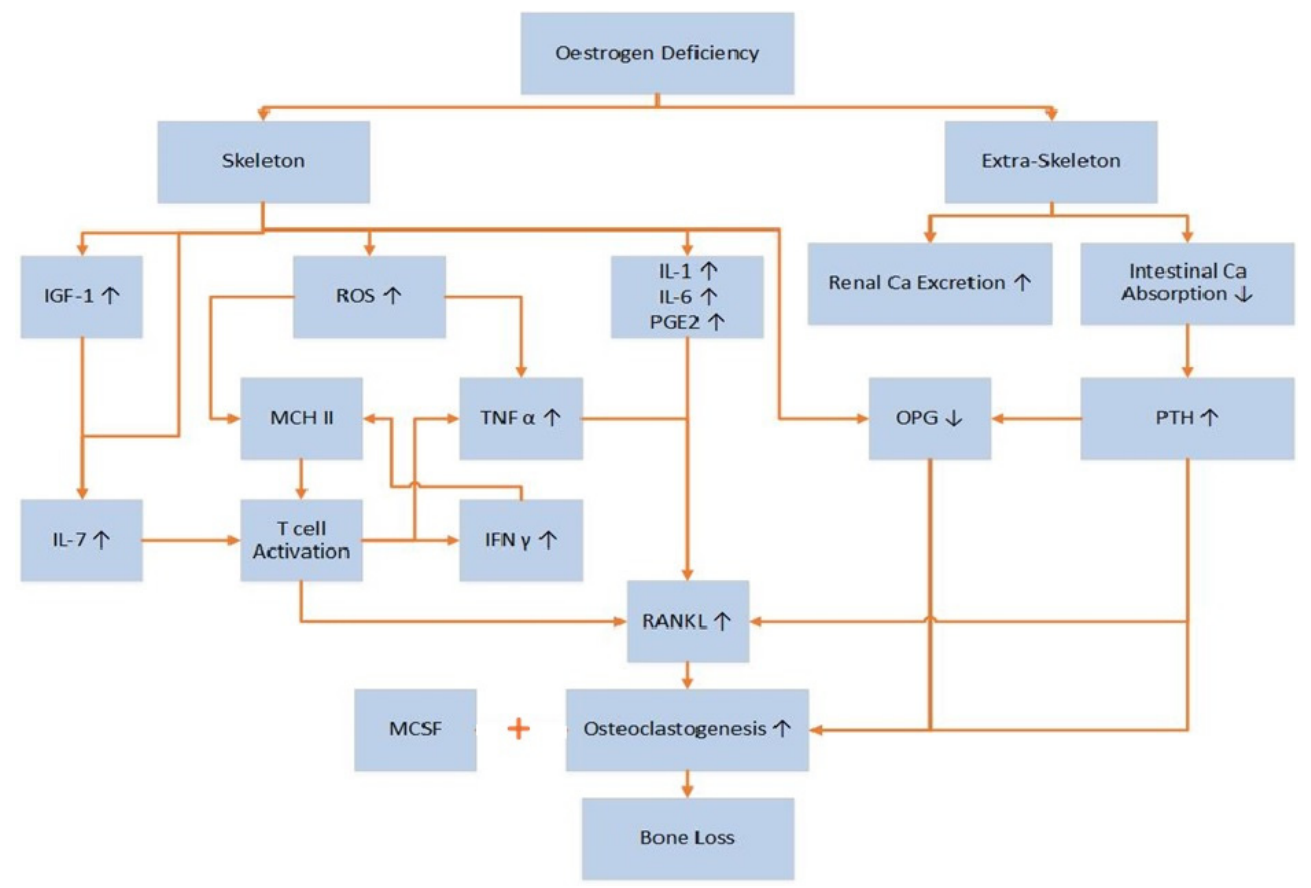

Figure 1. Occurrence of bone loss through estrogen deficiency (reference from [10,86]). Estrogen deficiency increases the production of IL-7 directly and via increased production of IGF-1. IL-7 activates T-cells to produce IFN- $\gamma$ and TNF- $\alpha$. Reactive oxygen species (ROS), along with IFN- $\gamma$, upregulate MHC II, located in antigen-presenting cells that may further activate T-cells. Activated T-cells produce RANKL and TNF- $\alpha$. Other cytokines, IL-1, IL-6, and PGE2, also increase the production of RANKL. Decreased osteoprotegerin (OPG) due to insufficient estrogen directly influences osteoclastogenesis. Beyond the skeletal activities, estrogen deficiency may increase renal calcium excretion while decreasing intestinal calcium absorption. This stimulates the parathyroid glands to produce $\mathrm{PTH}$, which can reduce the production of OPG and increase the production of RANKL and, therefore, increase bone resorption. All these actions together are involved in postmenopausal bone loss. 
Molecular markers of bone metabolism are widely used to assess bone-related disorders. These markers include enzymes and nonenzymatic peptides produced by bones. Bone formation or resorption markers correlate with the metabolic phase in which they are produced [38]. Short-term estrogen deficiency ( 3 weeks) is associated with low levels of bone formation markers in early postmenopausal women [87]. Interestingly, studies have shown that long-term estrogen deficiency increased both bone resorption and bone formation markers in postmenopausal women, suggestive of enhanced bone turnover with increased net bone loss [88-91]. Estrogen deficiency increases renal calcium excretion while decreasing intestinal calcium absorption [10], and the resultant fall in calcium levels can activate various bone resorption mechanisms that include PTH, osteocalcin, OPG, and the RANK/RANKL system [91-95]. These bone resorption markers are, therefore, found in the blood in higher concentrations in osteoporosis. Conversely, osteocalcin, which is secreted by osteoclasts, directly binds calcium and enables bone mineralization by increasing hydroxyapatite absorption and, thus, is a marker of bone formation [96]. However, insufficient calcium and phosphorous stores in osteoporotic women reduce hydroxyapatite crystal formation, leaving more osteocalcin free to circulate in the blood $[93,94]$. The molecular mechanisms responsible for these complex changes are not yet fully elucidated [88].

As mentioned earlier, oxidative stress can be coupled with osteoporosis. Oxidative stress occurs when there is an imbalance between the production of reactive oxygen species (ROS) and their neutralization by antioxidants. Reactive oxygen species are formed as a result of cellular respiration, enzymatic activities in mitochondria, and cellular responses to cytokines induced by external stimuli [76]. Reactive oxygen species include both highly reactive oxygen-containing molecules and free radicals such as hydroxyl $(\mathrm{OH})$, superoxide $\left(\mathrm{O}_{2}^{-}\right)$, and hydrogen peroxides $\left(\mathrm{H}_{2} \mathrm{O}_{2}\right)$ [40]. Free radicals can oxidize lipids and proteins, thus causing cell damage and altered function $[97,98]$. Reactive oxygen species suppress differentiation and proliferation of osteoblasts and are significantly involved in osteoclast differentiation and bone resorption $[99,100]$. Menopause increases oxidative stress; thus, the oxidized microenvironment produced by ROS plays a major role in causing postmenopausal osteoporosis $[85,99,101]$. Antioxidants are directly involved in the scavenging process of ROS. A lack of antioxidants may increase proinflammatory cytokines, especially tumor necrosis factor (TNF- $\alpha$ ), and thereby induce bone loss [98].

There are two cytokines primarily responsible for osteoclastogenesis: macrophage colony-stimulating factor (M-CSF) and receptor activator of nuclear factor kappa B ligand (RANKL), which are produced by bone marrow stromal cells and osteoblasts during bone remodeling [31]. The RANK (receptor activator of nuclear factor kappa B), RANKL, and OPG system has been identified as a primary regulator of the bone remodeling process. Osteoprotegerin (OPG), which is produced by osteoblasts, is considered to be a decoy receptor for RANKL. RANKL binds to its receptor RANK on osteoclast precursors in the presence of M-CSF. Upon this, osteoclast precursors differentiate and combine to form multinucleated osteoclasts, which can start bone resorption [85]. Due to insufficient estrogen levels in postmenopausal women, OPG is downregulated and RANKL activity upregulated, thereby increasing osteoclastogenesis [10].

\section{Carotenoid Lycopene: Chemistry and its Isomers}

To date, more than 700 carotenoids [102] have been identified, of which 40-50 are present in the human diet in fruits and vegetables [103]. However, only 20 have been found in human tissues or blood $[104,105]$. There are two classes of carotenoids: nonoxygenated carotenoids and oxygenated carotenoids. Nonoxygenated carotenoids are unsaturated hydrocarbons such as lycopene, $\alpha$-carotene, $\beta$-carotene, $\gamma$-carotene, and $\zeta$-carotene, whereas oxygenated carotenoids are the xanthophylls [18].

The major carotenoids found in the human body and human diet are $\beta$-carotene, $\alpha$-carotene, $\alpha$-cryptoxanthin, lutein, zeaxanthin, and lycopene [106,107]. Carotenoids are localized within chloroplasts and chromoplasts in plant cells. In chloroplasts, the carotenoids are found in association with proteins, whereas chromoplasts contain a crystalline form of carotenoids [108]. Lycopene, a 
member of the carotenoid pigment family, is responsible for the specific red color in many fruits and vegetables, best typified by fresh tomatoes and tomato products [107]. It is a lipid-soluble antioxidant produced by plants and some microorganisms. Unlike $\beta$-carotene, lycopene does not contain a terminal $\beta$-ionone ring and thus does not have provitamin A activity. Lycopene is an acyclic carotenoid containing 11 conjugated double-bonds in its all-trans-isomeric form or in various cis-configurations (Figure 2) [15]. Having 11 conjugated double-bonds, lycopene is theoretically assumed to have 2048 possible cis-trans-conformations in nature, but only a few have been identified so far. Due to its molecular structure, only certain cis-isomers exist, predominately 5-cis, 9-cis, 13-cis, and 15-cis. The most stable isomeric form is 5-cis, followed by all-trans, 9-cis, 13-cis, 15-cis, 7-cis, and, finally, 11-cis as the least stable [104].

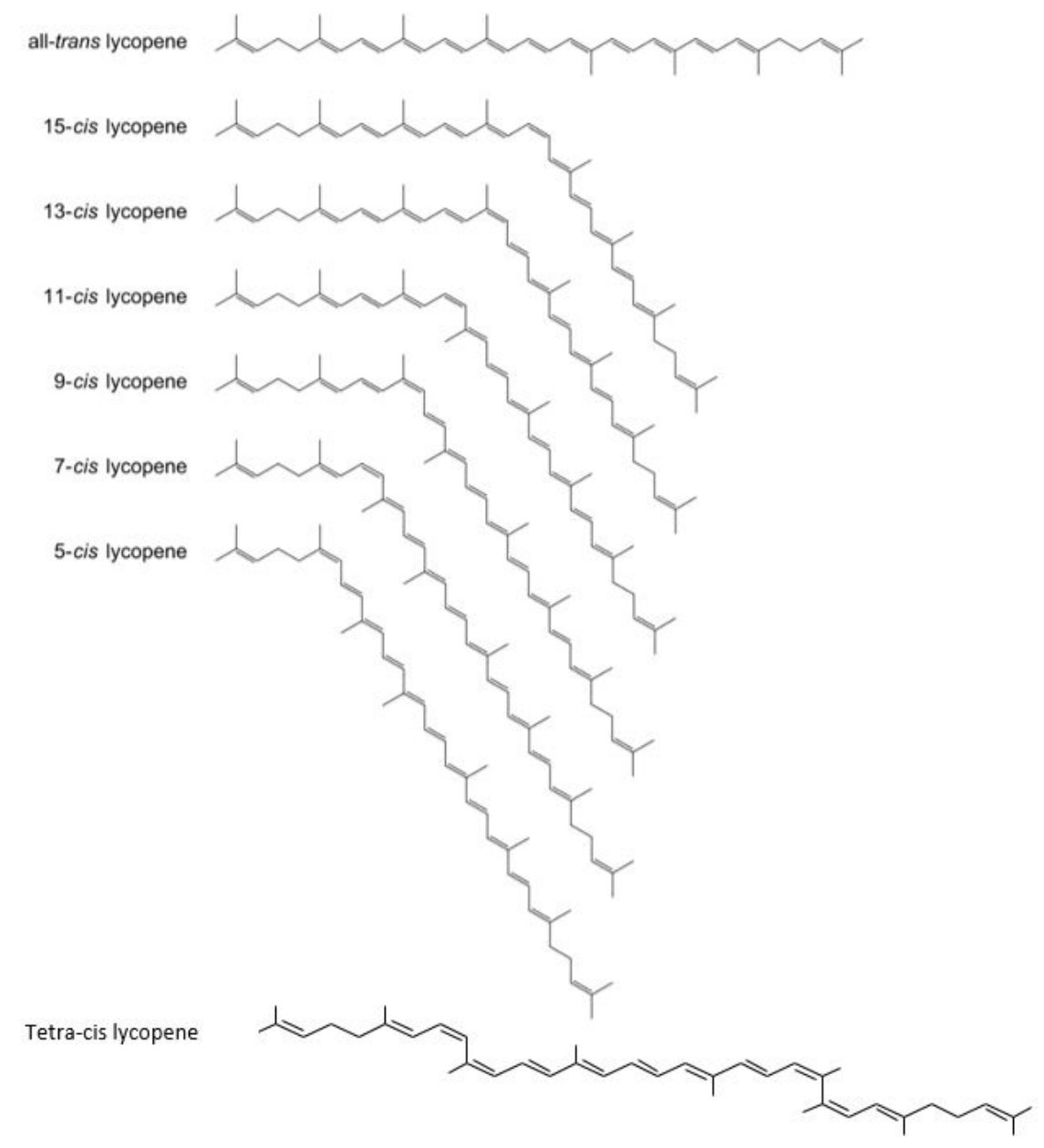

Figure 2. All-trans-lycopene and geometrical isomers.

Phytochemicals from fruits and vegetables are reported to aid in the maintenance of bone metabolism. In particular, carotenoids such as $\alpha$-carotene, $\beta$-carotene, canthaxanthin, and lycopene have demonstrated beneficial effects on skeletal health; there is a clear positive association between lycopene intake and reduced bone loss in humans [109]. Recently, an inverse relationship between hip fracture risk and consumption of carotenoids from fruits and vegetables was reported in men aged 45-74 [110]. Lycopene may suppress the formation of preosteoclasts from osteoprogenitor cells, thereby disrupting the osteoclast formation pathway [5].

\section{Lycopene Bioavailability, Absorption, and Metabolism}

The bioavailability of ingested lycopene is dependent on the dose of lycopene consumed, linkages between molecules in the food matrix, incorporation of fats, level of dietary fiber, interactions of 
lycopene with other carotenoids, and genetic factors [18,111]. Moreover, the bioavailability of lycopene differs depending on the isomeric form. In fact, cis-isomers of lycopene are estimated to be 8.5 times more bioavailable than all-trans lycopene [16]. The higher bioavailability of cis-isomers compared to all-trans is mostly due to the former's increased solubility in mixed micelles [112]. Compared to all-trans, cis-isomers are less likely to crystalize, highly soluble in oil, preferentially micellarized, readily taken up by intestinal cells, and easily transported within cells as well as across plasma and tissue matrices $[16,17]$. It is suggested that due to the polar nature and kinked forms of cis-isomers, they are less prone to crystallize $[18,113]$. Moreover, their preferential solubility is likely due to the smaller chain length of cis-isomers based on the bending of their structures, which may not be found in trans-lycopene isomers [114]. Lastly, thermal processing and mixing with oil can further increase the bioavailability of cis-lycopene present in tomatoes [18].

Interestingly, there are some natural sources, such as orange heirloom tomatoes, that contain more bioavailable cis-lycopene $[15,20]$. Almost $90 \%$ of the lycopene in orange heirloom tomatoes is in the cis-form compared to $90 \%$ of the all-trans-isomeric form of lycopene in red tomatoes [15]. This is due to a mutation known as tangerine in the carotenoid cis-trans-isomerase gene [115]. The cis-form gives a deep orange color to these tomatoes $[20,116]$. As the tangerine mutant lacks the ability to convert poly-cis-lycopene into all-trans, orange heirloom tomatoes predominantly accumulate tetra-cis-lycopene along with other precursors of lycopene such as phytoene, phytofluene, $\zeta$-carotene, and neurosporene [20].

Being lipid-soluble, lycopene is absorbed into the body following the same pathway as fats. The foremost step of lycopene absorption is the breakdown of the food matrix and the release of carotenoids into the gastrointestinal lumen. Mechanical alteration of the food structure by cooking and other methods of food processing may improve carotenoid release from the food matrix [117]. Lycopene then enters intestinal mucosal cells through the formation of bile acid micelles [118]. However, bile production depends on the amount of fat present in the diet; therefore, it is necessary to incorporate fat with the lycopene-containing food in order to increase its solubility [119]. In general, lycopene absorption from dietary sources ranges from 10-30\% [104], and, according to previous studies, a minimum $5-10 \mathrm{~g}$ of fat in a meal is required to ensure better absorption of carotenoids [120]. Once lycopene enters the enterocytes, it is either cleaved by $\beta$-carotene- $9^{\prime}, 10^{\prime}$-oxygenase (BCO2) to produce lycopenoids or incorporated into chylomicrons and secreted into lymphatic and blood circulation $[117,120]$. Absorbed lycopene can either accumulate in the liver or be packed into VLDL and HDL and thereby re-enter the blood. Via blood circulation, lycopene is deposited in extrahepatic organs, mainly the adrenal glands, adipose tissue, prostate, and testes [121]. Non-absorbed lycopene and the excess metabolic products are excreted from the body in urine and feces (Figure 3).

Lycopene concentrations in body tissues are higher than those of other carotenoids $[18,19,119]$. Half of the carotenoids in human serum are lycopene, and, among them, cis-isomers account for $58-73 \%$ of total lycopene in serum $[16,122,123]$. In the human body, lycopene is present at $1 \mathrm{nmol} / \mathrm{g}$ in adipose tissues and is found in higher concentrations of up to $20 \mathrm{nmol} / \mathrm{g}$ in testes, adrenal, and prostate glands [124]. Interestingly, neither lycopene nor other carotenoids have been found in brain stem tissues [125]. In addition, lycopene appears to have a long half-life; a recent study indicated that lycopene and its metabolites could be detected in the skin of humans up to 40 days after consumption [126].

The distribution of lycopene isomers is similar between plasma and tissues. Regardless of the isomeric forms of lycopene consumed, plasma and other tissues contain more cis-isomers, mainly the 5-cis-form [119,122]. Lycopene metabolites, or lycopenoids, can be the products of lycopene metabolism and oxidation. Kopec et al., were the first to identify the series of lycopenoids present in human blood, but they are found in plasma in only negligible amounts [127]. Similarly, lycopene metabolites can be found in some foods, but at 1000-fold lower concentrations than that of lycopene itself [127]. Some studies suggest that metabolites of lycopene may play a role in the biological 
activities of lycopene. However, only a limited number of studies have investigated the role of lycopene metabolites in vivo [128-132].

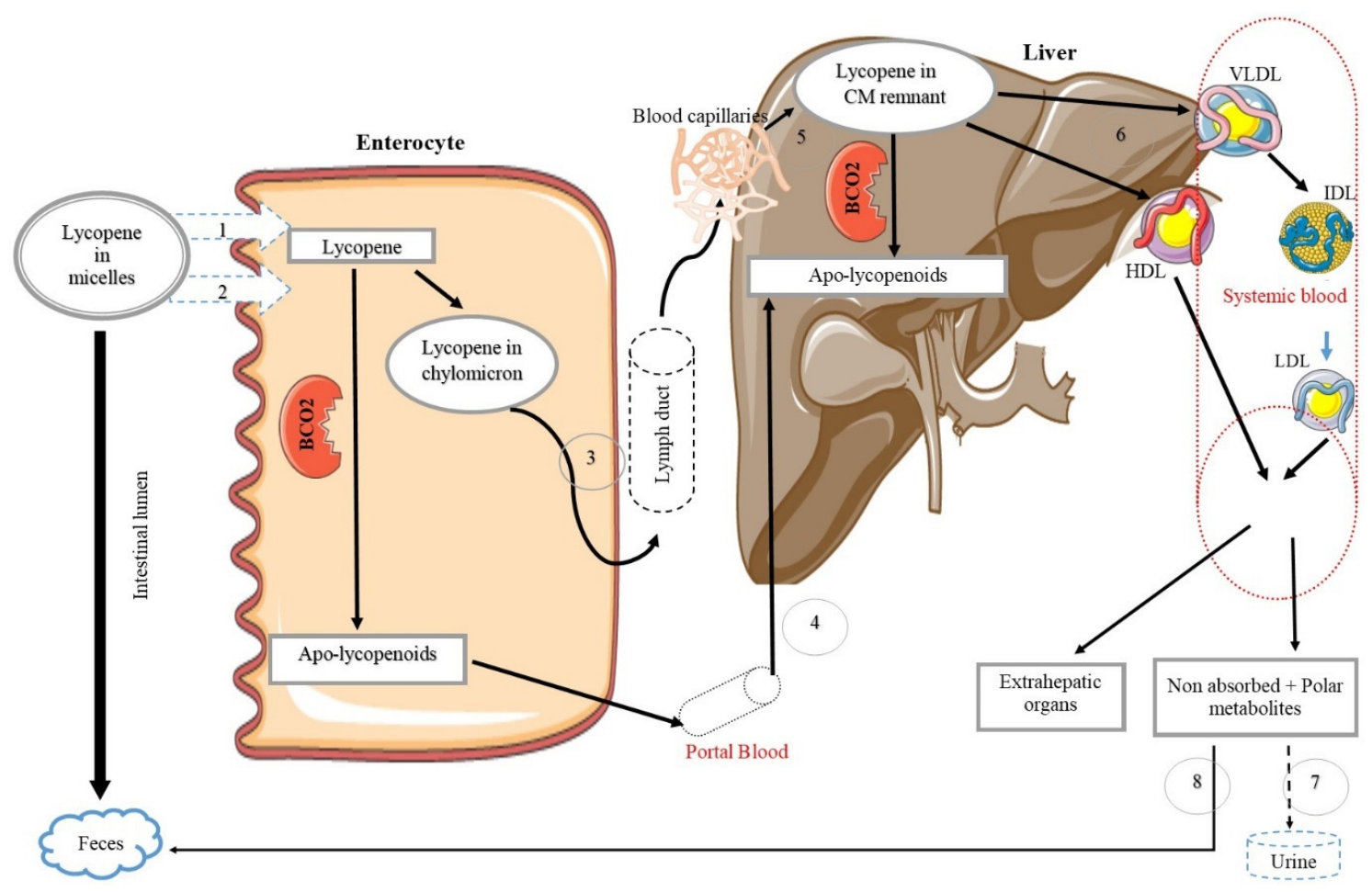

Figure 3. Simplified diagram of lycopene metabolism in the body (reference from [117,119,120,133-136]). Lycopene enters the enterocytes by active (1) and passive (2) transporters. There, it is packed in chylomicrons or converted to apo-lycopenoids by BCO2. Then, the chylomicrons or apo-lycopenoids are transferred to the liver via the lymphatic (3) and the portal venous (4) systems. Chylomicron remnants $(\mathrm{CM})$ pass to the blood capillaries and are then absorbed by the liver via receptor-mediated endocytosis (5). Lycopene is packaged in very low-density lipoproteins (VLDL) and high-density lipoproteins (HDL) by the liver and released to the systemic circulation (6). Lycopene travels to the extrahepatic organs through the systemic blood and is available there for its biological action. Polar metabolites are excreted in the urine by the kidneys (7), and non-absorbed lycopene is excreted through biliary excretion in feces (8).

\section{Evidence of the Effect of Lycopene on Bone Health}

Recently, the effect of lycopene on bone health has received additional attention from researchers [137]. The beneficial effects of lycopene on bone health have been studied using animal models, cell cultures, and epidemiological/clinical studies, as described below and in Tables $2-4$, in the context of postmenopausal osteoporosis.

\subsection{Epidemiological and Clinical Studies}

Human epidemiological studies have investigated the specific effects of tomato/lycopene on bone health, and the majority have shown a positive correlation between tomato/lycopene consumption and the prevention of bone loss (Table 2). The Framingham Osteoporosis study evaluated associations between total and isolated carotenoids with BMD in older adults ( 75 years old) [138]. An inverse relationship between lycopene levels and four-year bone loss in the lumbar spine in older women ( $\sim 5$ years old) was observed [138], and a follow-up study reported a protective effect of lycopene against hip fractures [139]. Mackinnon et al. reported a notable increase in a clinically relevant bone resorption marker, the crosslinked N-telopeptide of type 1 bone biomarker (NTx), as well as oxidative stress markers in postmenopausal women after one-month restriction of lycopene in the 
diet [140]. This also led to a drastic reduction in serum lycopene along with other carotenoids such as $\alpha$-carotene, $\beta$-carotene, lutein, and zeaxanthin [140]. Similarly, $30 \mathrm{mg} / \mathrm{d}$ lycopene supplementation in postmenopausal women in either juice or capsule form for four months decreased serum NTx level [141]. An epidemiological study in premenopausal women, which evaluated the effect of dietary carotenoids on bone mineral status, showed a positive correlation between lycopene intake and total body BMC and BMD [12]. Another study revealed lower levels of serum lycopene in postmenopausal women with osteoporosis compared to non-osteoporotic women [142].

Table 2. The effect of lycopene on postmenopausal bone loss based on human trials.

\begin{tabular}{|c|c|c|c|}
\hline Author and Year & Cohort & $\begin{array}{l}\text { Lycopene Formulation and } \\
\text { Study Duration }\end{array}$ & Outcome \\
\hline $\begin{array}{l}\text { Russo et al. (2020) } \\
\text { [143] }\end{array}$ & $\begin{array}{l}\text { Postmenopausal women } \\
(n=39) \\
\text { Age: } 63 \pm 7 \text { years }\end{array}$ & $\begin{array}{l}3.9 \mathrm{mg} / \text { day as tomato sauce } \\
3 \text { months }\end{array}$ & $\begin{array}{l}\text { Patients who consumed tomato sauce did } \\
\text { not show a significant loss of BMD } \\
\text { compared to control group }\end{array}$ \\
\hline $\begin{array}{l}\text { Mackinnon et al. } \\
\text { (2011) [141] }\end{array}$ & $\begin{array}{l}\text { Postmenopausal women } \\
(n=60) \\
\text { Age: } 50-60 \text { years }\end{array}$ & $\begin{array}{l}30 \mathrm{mg} / \text { day (regular tomato juice), } \\
70 \mathrm{mg} / \text { day (lycopene-rich } \\
\text { tomato juice), } \\
30 \mathrm{mg} / \text { day (Lyc-O-Mato } \\
\text { capsules) } \\
4 \text { months }\end{array}$ & $\begin{array}{l}\text { Lycopene intervention in capsule or juice } \\
\text { form supplying at least } 30 \mathrm{mg} / \text { day led to } \\
\text { decreased oxidative stress and bone } \\
\text { resorption markers }\end{array}$ \\
\hline $\begin{array}{l}\text { Mackinnon (2010) } \\
{[144]}\end{array}$ & $\begin{array}{l}\text { Postmenopausal women } \\
(n=45) \\
\text { Age: } 55 \text { years }\end{array}$ & $\begin{array}{l}43.33 \mathrm{mg} / \text { day supplementation } \\
4 \text { months }\end{array}$ & $\begin{array}{l}\text { Lycopene supplemented group showed } \\
\text { significantly lower levels of bone } \\
\text { resorption marker (NTx) }\end{array}$ \\
\hline $\begin{array}{l}\text { Mackinnon et al. } \\
\text { (2011) [140] }\end{array}$ & $\begin{array}{l}\text { Postmenopausal women } \\
(n=23) \\
\text { Age: } 50-60 \text { years }\end{array}$ & $\begin{array}{l}\text { Lycopene intake at baseline and } \\
\text { after one month of lycopene } \\
\text { restriction was } 3.5 \mathrm{mg} / \mathrm{d} \text { and } \\
0.13 \mathrm{mg} / \mathrm{d} \text {, respectively (using } \\
\text { 7-day dietary records) }\end{array}$ & $\begin{array}{l}\text { Bone resorption marker (NTx) was } \\
\text { increased after a month of lycopene } \\
\text { restriction } \\
\text { Endogenous antioxidant enzymes (SOD } \\
\text { and catalase) were decreased after a } \\
\text { month of lycopene restriction }\end{array}$ \\
\hline $\begin{array}{l}\text { Rao et al. (2007) } \\
\text { [145] }\end{array}$ & $\begin{array}{l}\text { Postmenopausal women } \\
(n=33) \\
\text { Age: } 50-60 \text { years }\end{array}$ & $\begin{array}{l}\text { Lycopene intake categorized } \\
\text { into four groups as ranged from } \\
1.76 \text { to } 7.35 \mathrm{mg} / \text { day (using } 7 \text {-day } \\
\text { dietary records) }\end{array}$ & $\begin{array}{l}\text { Serum NTx values dose-dependently } \\
\text { decreased } \\
\text { Postmenopausal women who consumed } \\
7.35 \text { mg lycopene/day had lower serum } \\
\text { NTx compared to the other three groups } \\
\text { No difference in bone formation markers }\end{array}$ \\
\hline
\end{tabular}

\subsection{Animal Trials}

Ovariectomy (OVX) is the most widely used surgical technique for the induction of osteoporosis in rodents and other animal models to mimic the hormonal and skeletal status of postmenopausal women [146]. Along with ovariectomy, most trials incorporate "sham"-operated animals as controls, which undergo surgery without the ovaries being removed [42]. Female rats are considered an excellent animal model for postmenopausal osteoporosis, but the age of the animals and site selection for harvesting the bones must be defined with care. Other experimental protocols related to bone loss have used interventions such as hormonal, dietary, and immobilization in rats, which had more variable effects on the rate of bone loss [147]. Ovariectomized rats fed a low calcium diet demonstrated rapid bone loss, supporting the use of this model as a gold standard for the evaluation of drugs for the treatment of osteoporosis [148,149]. Higher serum levels of osteocalcin, a biomarker of bone turnover, were measured in ovariectomized rats fed a low calcium diet compared to sham-operated rats $[38,149]$. Ovariectomized rats are considered most suitable for the evaluation of preventative agents for postmenopausal osteoporosis, although not for evaluation of treatment of osteoporosis over a long period of time $[42,150]$. This is because the rate of bone turnover in OVX rats become similar to their sham counterparts in studies $>12$ months, and also because the exact parameters for expected increases in the skeletal size of trabecular and cortical bone in the rat with long term OVX are not yet established [150].

Lycopene has been shown in multiple studies to dose-dependently increase BMD in ovariectomized rats [151]. Similarly, lycopene reduced bone fragility in ovariectomized rats and improved femoral bone 
energy, as assessed using a mechanical breaking test [14]. More recently, lycopene supplementation in ovariectomized rats was found to significantly alter levels of biomarkers of bone turnover in blood and urine, reducing bone resorption and increasing osteoblast activity. Simultaneously, lycopene treatment increased the enzyme action of glutathione peroxidase, catalase, and superoxide dismutase, and downregulated oxidative stress [99]. Taken together, these animal studies suggest that lycopene has bone-protective benefits (Table 3).

Table 3. The effects of lycopene on postmenopausal bone loss based on rodent trials.

\begin{tabular}{|c|c|c|c|}
\hline Author and Year & Animal Strain & $\begin{array}{l}\text { Lycopene Dose and } \\
\text { Study Duration }\end{array}$ & Outcome \\
\hline $\begin{array}{l}\text { Oliveira et al. (2019) } \\
\text { [152] }\end{array}$ & Female Wistar rats & $\begin{array}{l}10 \mathrm{mg} / \mathrm{kg} \text { BW/day } \\
4 \text { weeks pre-OVX } \\
\text { and } 8 \text { weeks } \\
\text { post-OVX }\end{array}$ & $\begin{array}{l}\text { Decreased bone loss in femur epiphysis in the } \\
\text { OVX + lycopene group compared to the OVX } \\
\text { control group }\end{array}$ \\
\hline Li et al. (2018) [153] & $\begin{array}{l}\text { Female } \\
\text { Sprague-Dawley rats }\end{array}$ & $\begin{array}{l}50 \mathrm{mg} / \mathrm{kg} \text { BW/day } \\
12 \text { weeks }\end{array}$ & $\begin{array}{l}\text { Higher bone volume and trabecular thickness } \\
\text { with low trabecular spaces in the OVX + lycopene } \\
\text { group compared to the OVX control group } \\
\text { Increased bone contact and bone area around the } \\
\text { implant were in the lycopene-treated group } \\
\text { compared to controls }\end{array}$ \\
\hline Ardawi et al. (2016) [99] & Female Wistar rats & $\begin{array}{l}15,30,45 \mathrm{mg} / \mathrm{kg} \mathrm{BW} \\
\text { per day } \\
12 \text { weeks }\end{array}$ & $\begin{array}{l}\text { Lycopene treatment dose-dependently enhanced } \\
\text { BMD and BMC at the lumbar spine and humerus } \\
\text { compared to OVX control group } \\
\text { Lycopene ( } 30 \text { and } 45 \mathrm{mg} / \mathrm{kg} \text { BW) increased bone } \\
\text { formation markers (serum-OC and serum PINP) } \\
\text { while bone resorption markers (serum-CTX-1 } \\
\text { and urine-DPD) were decreased }\end{array}$ \\
\hline Iimura et al. (2015) [14] & $\begin{array}{l}\text { Female } \\
\text { Sprague-Dawley } \\
\text { 6-week-old }\end{array}$ & $\begin{array}{l}0,50,100,200 \mathrm{mg} \\
\text { lycopene } / \mathrm{kg} \text { diet } / \text { day } \\
9 \text { weeks }\end{array}$ & $\begin{array}{l}\text { Lycopene }(100 \mathrm{mg} / \mathrm{kg}) \text { increased lumbar spine } \\
\text { BMD and femoral-breaking force compared to } \\
\text { OVX control group } \\
\text { Bone resorption markers were low in all } \\
\text { lycopene-treated groups }\end{array}$ \\
\hline Iimura et al. (2014) [13] & $\begin{array}{l}\text { Female } \\
\text { Sprague-Dawley } \\
\text { 6-week-old }\end{array}$ & $\begin{array}{l}0,50,100 \mathrm{mg} / \mathrm{kg} \text { diet } \\
\text { lycopene } \\
9 \text { weeks }\end{array}$ & $\begin{array}{l}\text { Lycopene }(100 \mathrm{mg} / \mathrm{kg}) \text { increased BMD of the } \\
\text { lumbar spine and the tibial proximal metaphysis } \\
\text { compared to OVX control group }\end{array}$ \\
\hline Liang et al. (2012) [151] & $\begin{array}{l}\text { Female Wistar rats } \\
\text { 8-week-old }\end{array}$ & $\begin{array}{l}\text { 20, } 30,40 \mathrm{mg} / \mathrm{kg} \\
\text { BW/day } \\
8 \text { weeks }\end{array}$ & $\begin{array}{l}\text { Lycopene ( } 30 \text { and } 40 \mathrm{mg} / \mathrm{kg} \mathrm{BW}) \\
\text { dose-dependently increased BMD and BMC in } \\
\text { OVX rats compared to OVX control group }\end{array}$ \\
\hline
\end{tabular}

\subsection{Bone Cell Culture Studies}

Multiple in vitro studies have demonstrated that lycopene and other carotenoids directly affect both osteoclasts and osteoblasts (Table 4). Ishimi and coworkers reported that osteoclast-like cell formation induced by $1 \alpha, 25(\mathrm{OH}) 2 \mathrm{D} 3$ (Calcitriol), IL-1 $\beta$, and parathyroid hormone was inhibited by retinoic acid and carotenoids, including $\beta$-carotene, canthaxanthin, and lycopene, with retinoic acid being most effective [154]. Park et al., also found retinoic acid to have the highest activity in inducing differentiation of the osteoblastic cell line MC3T3-E1, with retinol, $\beta$-carotene, lycopene, and canthaxanthin showing lesser but similar effectiveness [155]. Lycopene inhibited osteoclast formation and bone resorption by rat bone marrow cells in a model of parathyroid hormone-induced osteoclastogenesis [34]. More recently, human osteoclast and osteoblast precursor cells, treated with $500 \mathrm{nM}$ lycopene for 21 days, demonstrated reduced osteoclastogenesis while increasing osteoblastogenesis [156]. Lack of nuclear factor kappa $\mathrm{B}(\mathrm{NF} \mathrm{KB})$ may lead to a reduction in osteoclast precursors differentiating into mature osteoclasts, thereby reducing bone loss. Interestingly, some studies suggest that derivatives of carotenoids can downregulate the activity of NFKB activity, a regulator of cytokine expression $[8,157,158]$, suggesting $\mathrm{NF} \kappa \mathrm{B}$ modulation is a candidate pathway for lycopene's protective effects against osteoporosis. Taken together, evidence from in vitro studies suggest that lycopene has beneficial effects on bone health via molecular mechanisms that are summarized in Figure 4. 
Table 4. The effects of lycopene on bone cells (osteoblasts and osteoclasts).

\begin{tabular}{|c|c|c|c|}
\hline Author and Year & Cell Line & $\begin{array}{l}\text { Lycopene } \\
\text { Concentration }\end{array}$ & Outcome \\
\hline Russo et al. (2020) [143] & $\begin{array}{l}\text { Human osteoblast-like cell } \\
\text { line Saos-2 }\end{array}$ & 5 and $10 \mu \mathrm{M}$ & $\begin{array}{l}\text { Lycopene suppressed RANKL expression indicating } \\
\text { the reduction of bone resorption } \\
\text { Lycopene reduced the stimulatory effect of ALP within } \\
24 \mathrm{~h} \text { indicating possible role in mineralization }\end{array}$ \\
\hline $\begin{array}{l}\text { Oliveira et al. (2019) } \\
\text { [152] }\end{array}$ & $\begin{array}{l}\text { Osteoblastic cells from femur } \\
\text { medullary canals of } \\
\text { ovariectomized female rats }\end{array}$ & $1 \mu \mathrm{M}$ & $\begin{array}{l}\text { Lycopene upregulated the genes associated with bone } \\
\text { metabolism of osteoblastic cells within 3-10 days }\end{array}$ \\
\hline $\begin{array}{l}\text { Costa-Rodrigues et al. } \\
(2018)[156]\end{array}$ & $\begin{array}{l}\text { Osteoblastic cells (human } \\
\text { mesenchymal stem cells } \\
\text { bone-marrow-derived) } \\
\text { Osteoclastic cells (human } \\
\text { peripheral blood } \\
\text { mononuclear cells) }\end{array}$ & $5 \mathrm{nM}-50 \mu \mathrm{M}$ & $\begin{array}{l}\text { Lycopene }(\geq 500 \mathrm{nM}) \text { increased osteoblastic cell } \\
\text { proliferation and differentiation } \\
\text { Lycopene }(\geq 500 \mathrm{nM}) \text { significantly decreased osteoclast } \\
\text { differentiation }\end{array}$ \\
\hline Feng et al. (2010) [160] & RAW 264.7 cells & $1-10 \mu \mathrm{M}$ & $\begin{array}{l}\text { Lycopene dose-dependently inhibited the increase of } \\
\text { nitric oxide production and the secretion of IL- } 6 \text { when } \\
\text { RAW cells were stimulated by LPS }\end{array}$ \\
\hline Stefano et al. (2007) [161] & RAW 264.7 cells & $5,10,20 \mu \mathrm{M}$ & $\begin{array}{l}\text { Lycopene }(20 \mu \mathrm{M}) \text { significantly inhibited the ROS } \\
\text { accumulated due to addition of gliadin } \\
\text { Lycopene }(20 \mu \mathrm{M}) \text { significantly inhibited increase in } \\
\text { nitric oxide synthase levels }\end{array}$ \\
\hline Rao et al. (2003) [34] & $\begin{array}{l}\text { Osteoclast were generated } \\
\text { from bone marrow cells }\end{array}$ & $0.01,0.1,1,10 \mu \mathrm{M}$ & $\begin{array}{l}\text { Lycopene }(10 \mu \mathrm{M}) \text { significantly inhibited PTH } \\
\text { stimulated resorption by osteoclasts }\end{array}$ \\
\hline
\end{tabular}

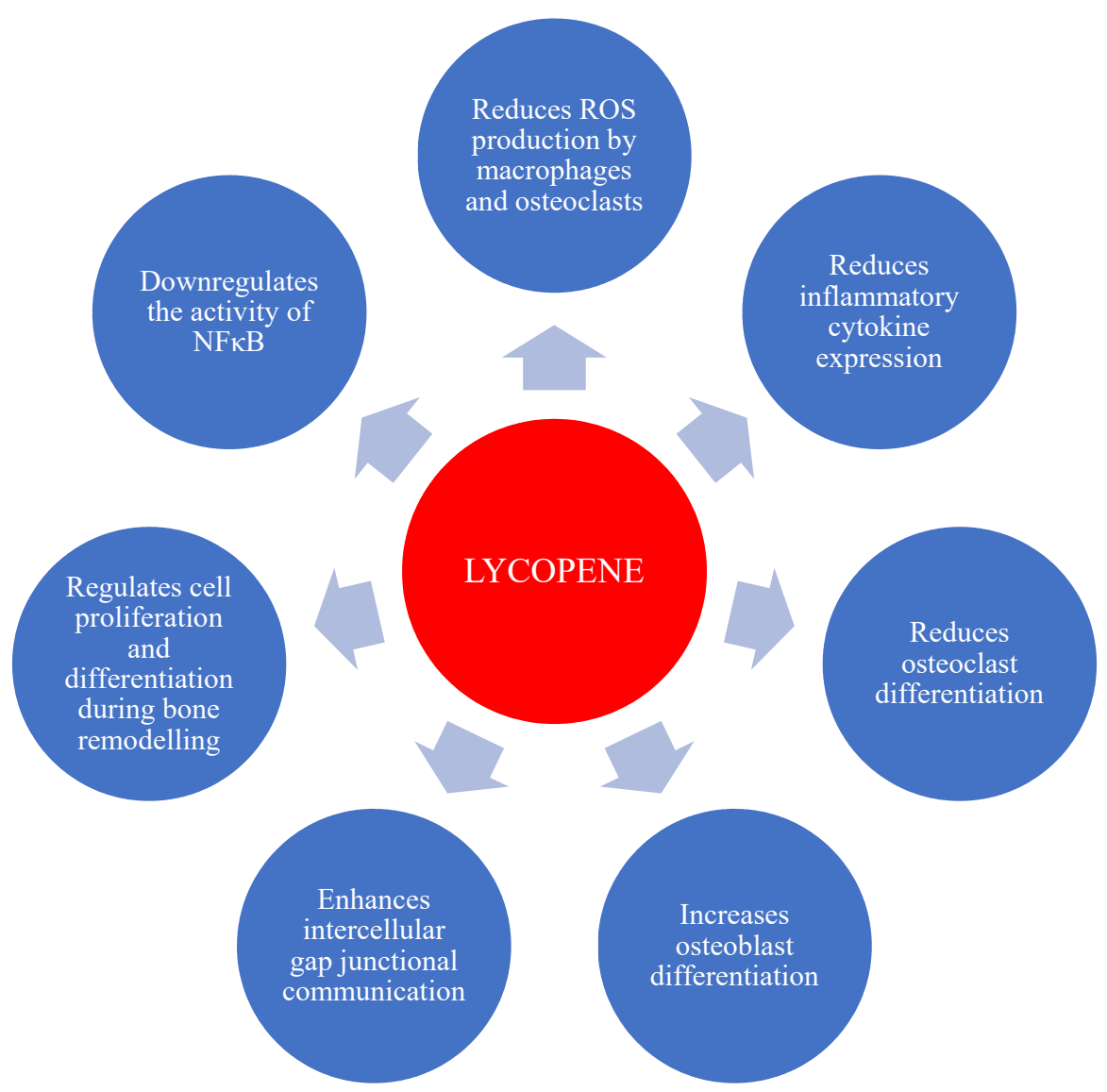

Figure 4. Schematic representation of the potential effects of lycopene on bone cells (reference from $[13,14,99]$. 


\section{Conclusions}

Postmenopausal bone loss is a public health issue in the aging population. Medications can prevent and treat bone loss in some patients but may have negative side effects. Phytochemicals present in fruits and vegetables play a major role in noncommunicable disease management. As summarized in this review, lycopene has a protective effect against bone loss; this has been demonstrated in in-vitro studies, in animal models of osteoporosis, and human clinical studies. The epidemiological and clinical studies discussed in this review have demonstrated that lycopene intake ( $\geq 30 \mathrm{mg} /$ day) is effective in reducing bone resorption markers in postmenopausal women [140,141]. Tomatoes are a major source of dietary lycopene; however, due to the relatively low bioavailability of all-trans-lycopene isomers found in red tomatoes, several techniques are used to increase bioavailability, such as adding oils or making cooked sauces and pastes. Other sources of more bioavailable lycopene can be found in nature. For example, orange heirloom tomatoes contain $>90 \%$ of lycopene in a cis-isomeric form, which is estimated to be 8.5 times more bioavailable than all-trans-lycopene [16]. Further studies are warranted to compare the relative benefits of these tomato varieties and lycopene isomers in protecting against bone loss.

Author Contributions: The manuscript was conceptualized and written through the contribution of all authors. All authors have read and agreed to the published version of the manuscript.

Funding: This research was partially funded by the Heritage Fruit Crop Research Trust (HFCRT) Wanganui, New Zealand (PR40335) and U.S.W. is supported by the Massey doctoral scholarship.

Acknowledgments: The figures were made using freely available resources: Smart Servier medical art (https://smart.servier.com/) and Creative Commons resources (https://creativecommons.org/licenses/by-nc-sa/3.0/).

Conflicts of Interest: The authors declare no conflict of interest. The funders had no role in the design of the study; in the collection, analyses, or interpretation of data; in the writing of the manuscript, or in the decision to publish the results.

\section{Abbreviations}

$\begin{array}{ll}\text { CKD } & \text { Chronic kidney disease } \\ \text { BMU } & \text { Basic multicellular unit } \\ \text { BMD } & \text { Bone mineral density } \\ \text { BMC } & \text { Bone mineral content } \\ \text { SD } & \text { Standard deviation } \\ \text { DEXA } & \text { Dual-energy X-ray absorptiometry } \\ \text { MRI } & \text { Magnetic resonance imaging } \\ \text { ROS } & \text { Reactive oxygen species } \\ \mathrm{OH}^{-} & \text {Hydroxyl } \\ \mathrm{O}_{2}{ }^{-} & \text {Superoxide } \\ \mathrm{H}_{2} \mathrm{O}_{2} & \text { Hydrogen peroxides } \\ \text { TNF } & \text { Tumor necrosis factor } \\ \text { OPG } & \text { Osteoprotegerin } \\ \text { M-CSF } & \text { Macrophage colony-stimulating factor } \\ \text { RANK } & \text { Receptor Activator of Nuclear Factor Kappa B } \\ \text { RANKL } & \text { Receptor Activator of Nuclear Factor Kappa B Ligand } \\ \text { IL } & \text { Interleukin } \\ \text { IGF } & \text { Insulin-like growth factor } \\ \text { IFN } & \text { Interferon } \\ \text { MHC } & \text { Major histocompatibility complex } \\ \text { PGE } & \text { Prostaglandin E2 } \\ \text { PTH } & \text { Parathyroid hormone } \\ & \end{array}$




$\begin{array}{ll}\text { BCO2 } & \text { B-carotene- } 9^{\prime}, 10^{\prime} \text {-oxygenase } \\ \text { VLDL } & \text { Very low-density lipoprotein } \\ \text { HDL } & \text { High-density lipoprotein } \\ \text { LDL } & \text { Low-density lipoprotein } \\ \text { IDL } & \text { Intermediate density lipoprotein } \\ \text { CM } & \text { Chylomicron } \\ \text { NTx } & \text { N-telopeptide of type } 1 \text { bone biomarker } \\ \text { SOD } & \text { Superoxide dismutase } \\ \text { OVX } & \text { Ovariectomy } \\ \text { CTX-1 } & \text { Carboxy terminal crosslinked telopeptides of type 1 collagen } \\ \text { DPD } & \text { Deoxypyridinoline } \\ \text { PINP } & \text { Procollagen type } 1 \text { N-terminal propeptide } \\ \text { NFkB } & \text { Nuclear factor kappa B } \\ \text { COL1A } & \text { Collagen type } 1 \text { alpha } \\ \text { CYP19A1 } & \text { Aromatase genes } \\ \text { ER } \alpha & \text { Estrogen receptor alpha genes }\end{array}$

\section{References}

1. Cooper, C.; Campion, G.; Melton, L.J., III. Hip fractures in the elderly: A world-wide projection. Osteoporos. Int. 1992, 2, 285-289. [CrossRef] [PubMed]

2. Szulc, P.; Bouxsein, M.L. Overview of osteoporosis: Epidemiology and clinical management. Vertebr. Fract. Initiat. Resour. Doc. 2011, 1, 1-65.

3. Wright, N.C.; Looker, A.C.; Saag, K.G.; Curtis, J.R.; Delzell, E.S.; Randall, S.; Dawson-Hughes, B. The recent prevalence of osteoporosis and low bone mass in the United States based on bone mineral density at the femoral neck or lumbar spine. J. Bone Miner. Res. 2014, 29, 2520-2526. [CrossRef]

4. Cauley, J.A.; Chalhoub, D.; Kassem, A.M.; Fuleihan, G.E.-H. Geographic and ethnic disparities in osteoporotic fractures. Nat. Rev. Endocrinol. 2014, 10, 338. [CrossRef] [PubMed]

5. Pandey, M.K.; Gupta, S.C.; Karelia, D.; Gilhooley, P.J.; Shakibaei, M.; Aggarwal, B.B. Dietary nutraceuticals as backbone for bone health. Biotechnol. Adv. 2018, 36, 1633-1648. [CrossRef] [PubMed]

6. Rao, L.; Rao, A. Oxidative stress and antioxidants in the risk of osteoporosis-Role of phytochemical antioxidants lycopene and polyphenol-containing nutritional supplements. In Phytochemicals_Isolation, Characterisation and Role in Human Health; Venketeshwer Rao, L.R., Ed.; InTech Open Access Publisher: Rijeka, Croatia, 2015; pp. 247-260.

7. International Osteoporosis Foundation. Facts and Statistics. Available online: https://www.iofbonehealth. org/facts-statistics (accessed on 5 May 2020).

8. Kini, U.; Nandeesh, B. Physiology of bone formation, remodeling, and metabolism. In Radionuclide and Hybrid Bone Imaging; Springer: Berlin/Heidelberg, Germany, 2012; pp. $29-57$.

9. Duque, G.; Troen, B.R. Understanding the mechanisms of senile osteoporosis: New facts for a major geriatric syndrome. J. Am. Geriatr. Soc. 2008, 56, 935-941. [CrossRef]

10. Sipos, W.; Pietschmann, P.; Rauner, M.; Kerschan-Schindl, K.; Patsch, J. Pathophysiology of osteoporosis. Wien. Med. Wochenschr. 2009, 159, 230-234. [CrossRef]

11. Sugiura, M.; Nakamura, M.; Ogawa, K.; Ikoma, Y.; Ando, F.; Shimokata, H.; Yano, M. Dietary patterns of antioxidant vitamin and carotenoid intake associated with bone mineral density: Findings from post-menopausal Japanese female subjects. Osteoporos. Int. 2011, 22, 143-152. [CrossRef]

12. Wattanapenpaiboon, N.; Lukito, W.; Wahlqvist, M.L.; Strauss, B.J. Dietary carotenoid intake as a predictor of bone mineral density. Asia Pac. J. Clin. Nutr. 2003, 12, 467-473.

13. Iimura, Y.; Agata, U.; Takeda, S.; Kobayashi, Y.; Yoshida, S.; Ezawa, I.; Omi, N. Lycopene intake facilitates the increase of bone mineral density in growing female rats. J. Nutr. Sci. Vitaminol. 2014, 60, 101-107. [CrossRef]

14. Iimura, Y.; Agata, U.; Takeda, S.; Kobayashi, Y.; Yoshida, S.; Ezawa, I.; Omi, N. The protective effect of lycopene intake on bone loss in ovariectomized rats. J. Bone Miner. Metab. 2015, 33, 270-278. [CrossRef] [PubMed] 
15. Burri, B.J.; Chapman, M.H.; Neidlinger, T.R.; Seo, J.S.; Ishida, B.K. Tangerine tomatoes increase total and tetra-cis-lycopene isomer concentrations more than red tomatoes in healthy adult humans. Int. J. Food Sci. Nutr. 2009, 60, 1-16. [CrossRef] [PubMed]

16. Cooperstone, J.L.; Ralston, R.A.; Riedl, K.M.; Haufe, T.C.; Schweiggert, R.M.; King, S.A.; Timmers, C.D.; Francis, D.M.; Lesinski, G.B.; Clinton, S.K. Enhanced bioavailability of lycopene when consumed as cis-isomers from tangerine compared to red tomato juice, a randomized, cross-over clinical trial. Mol. Nutr. Food Res. 2015, 59, 658-669. [CrossRef] [PubMed]

17. Ishida, B.; Roberts, J.; Chapman, M.; Burri, B. Processing tangerine tomatoes: Effects on lycopene-isomer concentrations and profile. J. Food Sci. 2007, 72, 307-312. [CrossRef]

18. Shi, J.; Maguer, M.L. Lycopene in tomatoes: Chemical and physical properties affected by food processing. Crit. Rev. Food Sci. Nutr. 2000, 40,1-42. [CrossRef]

19. Rao, A.; Waseem, Z.; Agarwal, S. Lycopene content of tomatoes and tomato products and their contribution to dietary lycopene. Food Res. Int. 1998, 31, 737-741. [CrossRef]

20. Cooperstone, J.L.; Francis, D.M.; Schwartz, S.J. Thermal processing differentially affects lycopene and other carotenoids in cis-lycopene containing, tangerine tomatoes. Food Chem. 2016, 210, 466-472. [CrossRef]

21. Unlu, N.Z.; Bohn, T.; Francis, D.; Clinton, S.K.; Schwartz, S.J. Carotenoid absorption in humans consuming tomato sauces obtained from tangerine or high- $\beta$-carotene varieties of tomatoes. J. Agric. Food Chem. 2007, 55, 1597-1603. [CrossRef]

22. Morgan, K.T. Nutritional determinants of bone health. J. Nutr. Elder. 2008, 27, 3-27. [CrossRef]

23. Bartl, R.; Frisch, B. Osteoporosis: Diagnosis, Prevention, Therapy, 2nd ed.; Springer: Berlin/Heidelberg, Germany, 2009; pp. 7-22.

24. Florencio-Silva, R.; Sasso, G.R.d.S.; Sasso-Cerri, E.; Simões, M.J.; Cerri, P.S. Biology of bone tissue: Structure, function, and factors that influence bone cells. Biomed Res. Int. 2015, 2015, 421746. [CrossRef]

25. Burr, D.B.; Akkus, O. Chapter 1-Bone Morphology and Organization. In Basic and Applied Bone Biology; Burr, D.B., Allen, M.R., Eds.; Academic Press: San Diego, CA, USA, 2014; pp. 3-25.

26. Alves, R. Osteoblast Differentiation and Bone: Relevant proteins, regulatory processes and the vascular connection. Ph.D. Thesis, Erasmus University, Rotterdam, The Netherlands, 2012.

27. McCormick, R.K. Osteoporosis: Integrating biomarkers and other diagnostic correlates into the management of bone fragility. Altern. Med. Rev. 2007, 12, 113. [PubMed]

28. Jilka, R.L.; Weinstein, R.S.; Bellido, T.; Parfitt, A.M.; Manolagas, S.C. Osteoblast programmed cell death (apoptosis): Modulation by growth factors and cytokines. J. Bone Miner. Res. 1998, 13, 793-802. [CrossRef] [PubMed]

29. Horcajada, M.-N.; Offord, E. Naturally plant-derived compounds: Role in bone anabolism. Curr. Mol. Pharmacol. 2012, 5, 205-218. [CrossRef]

30. Clarke, B. Normal bone anatomy and physiology. Clin. J. Am. Soc. Nephrol. 2008, 3, 131-139. [CrossRef] [PubMed]

31. Iñiguez-Ariza, N.M.; Clarke, B.L. Bone biology, signaling pathways, and therapeutic targets for osteoporosis. Maturitas 2015, 82, 245-255. [CrossRef]

32. Langdahl, B.; Ferrari, S.; Dempster, D.W. Bone modeling and remodeling: Potential as therapeutic targets for the treatment of osteoporosis. Ther. Adv. Musculoskelet. Dis. 2016, 8, 225-235. [CrossRef]

33. Baron, R.; Hesse, E. Update on bone anabolics in osteoporosis treatment: Rationale, current status, and perspectives. J. Clin. Endocrinol. Metab. 2012, 97, 311-325. [CrossRef]

34. Rao, L.G.; Krishnadev, N.; Banasikowska, K.; Rao, A.V. Lycopene 1-Effect on osteoclasts: Lycopene inhibits basal and parathyroid hormone-stimulated osteoclast formation and mineral resorption mediated by reactive oxygen species in rat bone marrow cultures. J. Med. Food 2003, 6, 69-78. [CrossRef]

35. Dempster, D.W.; Raisz, L.G. Bone physiology: Bone cells, modeling, and remodeling. In Nutrition and Bone Health; Holick, M., Nieves, J., Eds.; Humana Press: New York, NY, USA, 2015; pp. 37-56.

36. Manolagas, S.C. Birth and death of bone cells: Basic regulatory mechanisms and implications for the pathogenesis and treatment of osteoporosis. Endocr. Rev. 2000, 21, 115-137.

37. Hadjidakis, D.J.; Androulakis, I.I. Bone remodeling. Ann. N. Y. Acad. Sci. 2006, 1092, 385-396. [CrossRef]

38. Shetty, S.; Kapoor, N.; Bondu, J.D.; Thomas, N.; Paul, T.V. Bone turnover markers: Emerging tool in the management of osteoporosis. Indian J. Endocrinol. Metab. 2016, 20, 846. [PubMed] 
39. Siddiqui, J.A.; Partridge, N.C. Physiological bone remodeling: Systemic regulation and growth factor involvement. Physiology 2016, 31, 233-245. [CrossRef] [PubMed]

40. Rao, L.; Rao, A. Oxidative stress and antioxidants in the risk of osteoporosis-Role of the antioxidants lycopene and polyphenols. In Topics in Osteoporosis; Valdés-Flores, M., Ed.; InTech Open Access Publisher: Rijeka, Croatia, 2013; Volume 5, pp. 117-144.

41. Ferdous, H.; Afsana, F.; Qureshi, N.K.; Rouf, R.S.B. Osteoporosis: A Review. BIRDEM Med. J. 2016, 5, 30-36. [CrossRef]

42. Kruger, M.C.; Morel, P.C. Experimental control for the ovariectomized rat model: Use of sham versus nonmanipulated animal. J. Appl. Anim. Welf. Sci. 2016, 19, 73-80. [CrossRef] [PubMed]

43. Annapoorna, N.; Rao, G.V.; Reddy, N.; Rambabu, P.; Rao, K.S. An increased risk of osteoporosis during acquired immunodeficiency syndrome. Int. J. Med. Sci. 2004, 1, 152. [CrossRef] [PubMed]

44. Siris, E.; Boonen, S.; Mitchell, P.; Bilezikian, J.; Silverman, S. What's in a name? What constitutes the clinical diagnosis of osteoporosis? Osteoporos. Int. 2012, 23, 2093-2097. [CrossRef]

45. The National Institute of Health. Bone Mass Measurement: What the Numbers Mean. Available online: https://www.bones.nih.gov/health-info/bone/bone-health/bone-mass-measure (accessed on 5 May 2020).

46. Adler, R.A. Update on osteoporosis in men. Best Pract. Res. Clin. Endocrinol. Metab. 2018, 32, 759-772. [CrossRef]

47. Feng, X.; McDonald, J.M. Disorders of bone remodeling. Annu. Rev. Pathol. 2011, 6, 121-145. [CrossRef]

48. Nieves, J.W.; Cosman, F. Impact of Nutrition on Medications for Osteoporosis. In Nutrition and Bone Health; Springer: Berlin/Heidelberg, Germany, 2015; pp. 681-686.

49. International Osteoporosis Foundation. Treatment. Available online: https://www.osteoporosis.foundation/ health-professionals/treatment (accessed on 2 August 2020).

50. Ferrari, S.; Karasik, D. Gene-Diet Interactions on Bone. In Nutrition and Bone Health; Holick, M., Nieves, J., Eds.; Humana Press: New York, NY, USA, 2015; pp. 21-36.

51. Ralston, S.H. Osteoporosis as an hereditary disease. Clin. Rev. Bone Miner. Metab. 2010, 8, 68-76. [CrossRef]

52. Spotila, L.D.; Constantinou, C.D.; Sereda, L.; Ganguly, A.; Riggs, B.L.; Prockop, D.J. Mutation in a gene for type I procollagen (COL1A2) in a woman with postmenopausal osteoporosis: Evidence for phenotypic and genotypic overlap with mild osteogenesis imperfecta. Proc. Natl. Acad. Sci. USA 1991, 88, 5423-5427. [CrossRef]

53. Prockop, D.J.; Colige, A.; Helminen, H.; Khillan, J.; Pereira, R.; Vandenberg, P. Mutations in type 1 procollagen that cause osteogenesis imperfecta: Effects of the mutations on the assembly of collagen into fibrils, the basis of phenotypic variations, and potential antisense therapies. J. Bone Miner. Res. 1993, 8, 489-492. [CrossRef] [PubMed]

54. Marini, J.C.; Forlino, A.; Cabral, W.A.; Barnes, A.M.; San Antonio, J.D.; Milgrom, S.; Hyland, J.C.; Körkkö, J.; Prockop, D.J.; De Paepe, A. Consortium for osteogenesis imperfecta mutations in the helical domain of type I collagen: Regions rich in lethal mutations align with collagen binding sites for integrins and proteoglycans. Hum. Mutat. 2007, 28, 209-221. [CrossRef] [PubMed]

55. Morishima, A.; Grumbach, M.M.; Simpson, E.R.; Fisher, C.; Qin, K. Aromatase deficiency in male and female siblings caused by a novel mutation and the physiological role of estrogens. J. Clin. Endocrinol. Metab. 1995, 80, 3689-3698. [PubMed]

56. Smith, E.P.; Boyd, J.; Frank, G.R.; Takahashi, H.; Cohen, R.M.; Specker, B.; Williams, T.C.; Lubahn, D.B.; Korach, K.S. Estrogen resistance caused by a mutation in the estrogen-receptor gene in a man. N. Engl. J. Med. 1994, 331, 1056-1061. [CrossRef]

57. Sullivan, S.D.; Lehman, A.; Nathan, N.K.; Thomson, C.A.; Howard, B.V. Age of Menopause and Fracture Risk in Post-Menopausal Women Randomized to Calcium+ Vitamin D, Hormone Therapy, or the combination: Results from the Women's Health Initiative Clinical Trials. Menopause 2017, 24, 371. [CrossRef]

58. Dawson-Hughes, B.; Heaney, R.P.; Holick, M.F.; Lips, P.; Meunier, P.J.; Vieth, R. Estimates of optimal vitamin D status. Osteoporos. Int. 2005, 16, 713-716. [CrossRef]

59. Joint FAO/WHO Committee on Food Additives (JECFA). Evaluation of certain food additives and contaminants: Sixty-eighth report of the Joint FAO/WHO Expert Committee on Food Additives. In WHO Technical Repport Series; World Helath Organization: Geneva, Switserland, 2007; Volume 68.

60. Melton, L.J., III; Achenbach, S.J.; Gebhart, J.B.; Babalola, E.O.; Atkinson, E.J.; Bharucha, A.E. Influence of hysterectomy on long-term fracture risk. Fertil. Steril. 2007, 88, 156-162. [CrossRef] 
61. Kanis, J.A.; Johansson, H.; Johnell, O.; Oden, A.; De Laet, C.; Eisman, J.A.; Pols, H.; Tenenhouse, A. Alcohol intake as a risk factor for fracture. Osteoporos. Int. 2005, 16, 737-742. [CrossRef]

62. Fazeli, P.K.; Klibanski, A. Effects of anorexia nervosa on bone metabolism. Endocr. Rev. 2018, 39, 895-910. [CrossRef]

63. Kanis, J.A.; Johnell, O.; Odén, A.; Johansson, H.; De Laet, C.; Eisman, J.; Fujiwara, S.; Kroger, H.; McCloskey, E.; Mellstrom, D. Smoking and fracture risk: A meta-analysis. Osteoporos. Int. 2005, 16, 155-162. [CrossRef]

64. Kanis, J.; Johansson, H.; Odén, A.; Johnell, O.; De Laet, C.; Eisman, J.; McCloskey, E.; Mellstrom, D.; Melton III, L.; Pols, H. A family history of fracture and fracture risk: A meta-analysis. Bone 2004, 35, 1029-1037. [CrossRef]

65. Seeman, E.; Hopper, J.L.; Bach, L.A.; Cooper, M.E.; Parkinson, E.; McKay, J.; Jerums, G. Reduced bone mass in daughters of women with osteoporosis. N. Engl. J. Med. 1989, 320, 554-558. [CrossRef] [PubMed]

66. De Laet, C.; Kanis, J.; Odén, A.; Johanson, H.; Johnell, O.; Delmas, P.; Eisman, J.; Kroger, H.; Fujiwara, S.; Garnero, P. Body mass index as a predictor of fracture risk: A meta-analysis. Osteoporos. Int. 2005, 16, 1330-1338. [CrossRef] [PubMed]

67. Kanis, J.; Johnell, O.; De Laet, C.; Johansson, H.; Odén, A.; Delmas, P.; Eisman, J.; Fujiwara, S.; Garnero, P.; Kroger, H. A meta-analysis of previous fracture and subsequent fracture risk. Bone 2004, 35, 375-382. [CrossRef]

68. Misra, M.; Golden, N.H.; Katzman, D.K. State of the art systematic review of bone disease in anorexia nervosa. Int. J. Eat. Disord. 2016, 49, 276-292. [CrossRef]

69. Moayyeri, A.; Luben, R.N.; Bingham, S.A.; Welch, A.A.; Wareham, N.J.; Khaw, K.T. Measured height loss predicts fractures in middle-aged and older men and women: The EPIC-Norfolk prospective population study. J. Bone Miner. Res. 2008, 23, 425-432. [CrossRef]

70. Bass, S.L.; Saxon, L.; Daly, R.; Turner, C.H.; Robling, A.G.; Seeman, E.; Stuckey, S. The effect of mechanical loading on the size and shape of bone in pre-, peri-, and postpubertal girls: A study in tennis players. J. Bone Miner. Res. 2002, 17, 2274-2280. [CrossRef]

71. Kemmler, W.; Lauber, D.; Weineck, J.; Hensen, J.; Kalender, W.; Engelke, K. Benefits of 2 years of intense exercise on bone density, physical fitness, and blood lipids in early postmenopausal osteopenic women: Results of the Erlangen Fitness Osteoporosis Prevention Study (EFOPS). Arch. Intern. Med. 2004, 164, 1084-1091. [CrossRef] [PubMed]

72. International Osteoporosis Foundation. Fixed Risk. Available online: https://www.osteoporosis.foundation/ health-professionals/about-osteoporosis/risk-factors/fixed-risks (accessed on 25 August 2020).

73. Tinetti, M.E. Preventing falls in elderly persons. N. Engl. J. Med. 2003, 348, 42-49. [CrossRef]

74. International Osteoporosis Foundation. About Osteoporosis. Available online: https://www.osteoporosis. foundation/health-professionals/about-osteoporosis (accessed on 24 July 2020).

75. Becker, C. Pathophysiology and clinical manifestations of osteoporosis. Clin. Cornerstone 2006, 8, 19-27. [CrossRef]

76. Jahanian, E.; Karimifar, M.; Rafieian-Kopaei, M. Antioxidants as a novel way to alleviate the adverse effects of oxidative stress in osteoporosis. J. Parathyr. Dis. 2016, 4, 61.

77. Kim, N.; Choi, H.-R.; Kim, S.-W.; Kim, B.-S.; Won, C.-W.; Kim, S.-Y. Association between bone mineral density and sleep duration in the Korean elderly population. Korean J. Fam. Med. 2014, 35, 90. [CrossRef] [PubMed]

78. Kobayashi, D.; Takahashi, O.; Deshpande, G.A.; Shimbo, T.; Fukui, T. Association between osteoporosis and sleep duration in healthy middle-aged and elderly adults: A large-scale, cross-sectional study in Japan. Sleep Breath 2012, 16, 579-583. [CrossRef]

79. Hill, S.M.; Spriggs, L.L.; Simon, M.A.; Muraoka, H.; Blask, D.E. The growth inhibitory action of melatonin on human breast cancer cells is linked to the estrogen response system. Cancer Lett. 1992, 64, 249-256. [CrossRef]

80. Ochs-Balcom, H.M.; Hovey, K.M.; Andrews, C.; Cauley, J.A.; Hale, L.; Li, W.; Bea, J.W.; Sarto, G.E.; Stefanick, M.L.; Stone, K.L. Short sleep is associated with low bone mineral density and osteoporosis in the Women's Health Initiative. J. Bone Miner. Res. 2020, 35, 261-268. [CrossRef]

81. Fu, X.; Zhao, X.; Lu, H.; Jiang, F.; Ma, X.; Zhu, S. Association between sleep duration and bone mineral density in Chinese women. Bone 2011, 49, 1062-1066. [CrossRef]

82. Wang, K.; Wu, Y.; Yang, Y.; Chen, J.; Zhang, D.; Hu, Y.; Liu, Z.; Xu, J.; Shen, Q.; Zhang, N. The associations of bedtime, nocturnal, and daytime sleep duration with bone mineral density in pre-and post-menopausal women. Endocrine 2015, 49, 538-548. [CrossRef] 
83. Niu, J.; Sahni, S.; Liao, S.; Tucker, K.L.; Dawson-Hughes, B.; Gao, X. Association between sleep duration, insomnia symptoms and bone mineral density in older Boston Puerto Rican adults. PLoS ONE 2015, 10, e0132342. [CrossRef]

84. Khosla, S.; Oursler, M.J.; Monroe, D.G. Estrogen and the skeleton. Trends Endocrinol. Metab. 2012, $23,576-581$. [CrossRef]

85. Okman-Kilic, T. Estrogen deficiency and osteoporosis. In Advances in Osteoporosis; Dionyssiotis, Y., Ed.; InTech Open Access Publisher: Rijeka, Croatia, 2015; pp. 7-17.

86. Weitzmann, M.N.; Pacifici, R. Estrogen deficiency and bone loss: An inflammatory tale. J. Clin. Investig. 2006, 116, 1186-1194. [CrossRef]

87. Charatcharoenwitthaya, N.; Khosla, S.; Atkinson, E.J.; McCready, L.K.; Riggs, B.L. Effect of blockade of TNF- $\alpha$ and interleukin-1 action on bone resorption in early postmenopausal women. J. Bone Miner. Res. 2007, 22, 724-729. [CrossRef] [PubMed]

88. Garnero, P.; Sornay-Rendu, E.; Chapuy, M.C.; Delmas, P.D. Increased bone turnover in late postmenopausal women is a major determinant of osteoporosis. J. Bone Miner. Res. 1996, 11, 337-349. [CrossRef] [PubMed]

89. Dresner-Pollak, R.; Parker, R.A.; Poku, M.; Thompson, J.; Seibel, M.J.; Greenspan, S.L. Biochemical Markers of Bone Turnover Reflect Femoral Bone Loss in Elderly Women. Calcif. Tissue Int. 1996, 59, 328-333. [CrossRef] [PubMed]

90. Wu, X.-Y.; Li, H.-L.; Xie, H.; Luo, X.-H.; Peng, Y.-Q.; Yuan, L.-Q.; Sheng, Z.-F.; Dai, R.-C.; Wu, X.-P.; Liao, E.-Y. Age-related bone turnover markers and osteoporotic risk in native Chinese women. BMC Endocr. Disord. 2014, 14, 8. [CrossRef]

91. Iki, M.; Akiba, T.; Matsumoto, T.; Nishino, H.; Kagamimori, S.; Kagawa, Y.; Yoneshima, H.; Group, J.S. Reference database of biochemical markers of bone turnover for the Japanese female population. Japanese Population-based Osteoporosis (JPOS) Study. Osteoporos. Int. 2004, 15, 981-991. [CrossRef]

92. Yasuda, H.; Shima, N.; Nakagawa, N.; Yamaguchi, K.; Kinosaki, M.; Mochizuki, S.-i.; Tomoyasu, A.; Yano, K.; Goto, M.; Murakami, A. Osteoclast differentiation factor is a ligand for osteoprotegerin/osteoclastogenesis-inhibitory factor and is identical to TRANCE/RANKL. Proc. Natl. Acad. Sci. USA 1998, 95, 3597-3602. [CrossRef]

93. Jagtap, V.R.; Ganu, J.V.; Nagane, N.S. BMD and serum intact osteocalcin in postmenopausal osteoporosis women. Indian J. Clin. Biochem. 2011, 26, 70-73. [CrossRef]

94. Kalaiselvi, V.; Prabhu, K.; Mani Ramesh, V.V. The association of serum osteocalcin with the bone mineral density in postmenopausal women. J. Clin. Diagn. Res. 2013, 7, 814.

95. Tariq, S.; Tariq, S.; Lone, K.P.; Khaliq, S. Alkaline phosphatase is a predictor of Bone Mineral Density in postmenopausal females. Pak. J. Med. Sci. 2019, 35, 749. [CrossRef]

96. Zoch, M.L.; Clemens, T.L.; Riddle, R.C. New insights into the biology of osteocalcin. Bone 2016, 82, 42-49. [CrossRef]

97. Wauquier, F.; Leotoing, L.; Coxam, V.; Guicheux, J.; Wittrant, Y. Oxidative stress in bone remodelling and disease. Trends Mol. Med. 2009, 15, 468-477. [CrossRef] [PubMed]

98. Domazetovic, V.; Marcucci, G.; Iantomasi, T.; Brandi, M.L.; Vincenzini, M.T. Oxidative stress in bone remodeling: Role of antioxidants. Clin. Cases Miner. Bone. Metab. 2017, 14, 209-216. [CrossRef]

99. Ardawi, M.-S.M.; Badawoud, M.H.; Hassan, S.M.; Rouzi, A.A.; Ardawi, J.M.; AlNosani, N.M.; Qari, M.H.; Mousa, S.A. Lycopene treatment against loss of bone mass, microarchitecture and strength in relation to regulatory mechanisms in a postmenopausal osteoporosis model. Bone 2016, 83, 127-140. [CrossRef] [PubMed]

100. Callaway, D.A.; Jiang, J.X. Reactive oxygen species and oxidative stress in osteoclastogenesis, skeletal aging and bone diseases. J. Bone Miner. Metab. 2015, 33, 359-370. [CrossRef] [PubMed]

101. Mendoza, C.C.C.; Zamarripa, C.A.J. Menopause Induces Oxidative Stress in Oxidative Stress and Chronic Degenerative Diseases-A Role for Antioxidants; Morales-González, J.A., Ed.; InTech Open Access Publisher: Rijeka, Croatia, 2013; pp. 289-307.

102. Britton, G.; Liaaen-Jensen, S.; Pfander, H. Carotenoids: Handbook; Birkhäuser: Basel, Switzerland, 2012.

103. Khachik, F. Distribution and metabolism of dietary carotenoids in humans as a criterion for development of nutritional supplements. Pure Appl. Chem. 2006, 78, 1551-1557. [CrossRef]

104. Rao, A.V.; Rao, L.G. Carotenoids and human health. Pharmacol. Res. 2007, 55, 207-216. [CrossRef]

105. Fiedor, J.; Burda, K. Potential role of carotenoids as antioxidants in human health and disease. Nutrients 2014, 6, 466-488. [CrossRef] 
106. Bacanli, M.; BaŞAran, N.; BaŞAran, A.A. Lycopene: Is it Beneficial to Human Health as an Antioxidant? Turk. J. Pharm. Sci. 2017, 14, 311-318. [CrossRef]

107. Viuda-Martos, M.; Sanchez-Zapata, E.; Sayas-Barberá, E.; Sendra, E.; Pérez-Álvarez, J.; Fernández-López, J. Tomato and tomato byproducts. Human health benefits of lycopene and its application to meat products: A review. Crit. Rev. Food Sci. Nutr. 2014, 54, 1032-1049. [CrossRef]

108. Schieber, A.; Carle, R. Occurrence of carotenoid cis-isomers in food: Technological, analytical, and nutritional implications. Trends Food Sci. Technol. 2005, 16, 416-422. [CrossRef]

109. Hunter, D.C.; Skinner, M.A.; Lister, C.E. Impact of phytochemicals on maintaining bone and joint health. Nutrition 2008, 24, 390-392. [CrossRef] [PubMed]

110. Dai, Z.; Wang, R.; Ang, L.W.; Low, Y.L.; Yuan, J.M.; Koh, W.P. Protective effects of dietary carotenoids on risk of hip fracture in men: The Singapore Chinese Health Study. J. Bone Miner. Res. 2014, 29, 408-417. [CrossRef] [PubMed]

111. Castenmiller, J.J.; West, C.E. Bioavailability and bioconversion of carotenoids. Annu. Rev. Nutr. 1998, 18, 19-38. [CrossRef]

112. Unlu, N.Z.; Bohn, T.; Francis, D.M.; Nagaraja, H.N.; Clinton, S.K.; Schwartz, S.J. Lycopene from heat-induced cis-isomer-rich tomato sauce is more bioavailable than from all-trans-rich tomato sauce in human subjects. Br. J. Nutr. 2007, 98, 140-146. [CrossRef]

113. Meléndez-Martínez, A.J.; Paulino, M.; Stinco, C.M.; Mapelli-Brahm, P.; Wang, X.-D. Study of the time-course of cis/trans (Z/E) isomerization of lycopene, phytoene, and phytofluene from tomato. J. Agric. Food Chem. 2014, 62, 12399-12406. [CrossRef]

114. Boileau, A.C.; Merchen, N.R.; Wasson, K.; Atkinson, C.A.; Erdman, J.W., Jr. Cis-lycopene is more bioavailable than trans-lycopene in vitro and in vivo in lymph-cannulated ferrets. Nutr. J. 1999, 129, 1176-1181. [CrossRef] [PubMed]

115. Kachanovsky, D.E.; Filler, S.; Isaacson, T.; Hirschberg, J. Epistasis in tomato color mutations involves regulation of phytoene synthase 1 expression by cis-carotenoids. Proc. Natl. Acad. Sci. USA 2012, 109, 19021-19026. [CrossRef] [PubMed]

116. Englert, G.; Brown, B.O.; Moss, G.P.; Weedon, B.C.; Britton, G.; Goodwin, T.W.; Simpson, K.L.; Williams, R.J. Prolycopene, a tetra-cis-carotene with two hindered cis-double bonds. J. Chem. Soc. Chem. Comm. 1979, 12, 545-547. [CrossRef]

117. Wang, X.-D. Lycopene metabolism and its biological significance. Am. J. Clin. Nutr. 2012, 96, 1214-1222. [CrossRef]

118. Furr, H.C.; Clark, R.M. Intestinal absorption and tissue distribution of carotenoids. J. Nutr. Biochem. 1997, 8, 364-377. [CrossRef]

119. Boileau, T.W.-M.; Boileau, A.C.; Erdman, J.W., Jr. Bioavailability of all-trans and cis-Isomers of Lycopene. Exp. Biol. Med. 2002, 227, 914-919. [CrossRef] [PubMed]

120. Anese, M.; Mirolo, G.; Fabbro, A.; Lippe, G. Lycopene bioaccessibility and bioavailability from processed foods. J. Sci. Ind. Res. 2013, 72, 543-547.

121. Bramley, P.M. Is lycopene beneficial to human health? Phytochemistry 2000, 54, 233-236. [CrossRef]

122. Schierle, J.; Bretzel, W.; Bühler, I.; Faccin, N.; Hess, D.; Steiner, K.; Schüep, W. Content and isomeric ratio of lycopene in food and human blood plasma. Food Chem. 1997, 59, 459-465. [CrossRef]

123. Marković, K.; Hruškar, M.; Vahčić, N. Lycopene content of tomato products and their contribution to the lycopene intake of Croatians. Nutr. Res. 2006, 26, 556-560. [CrossRef]

124. Stahl, W.; Sies, H. Lycopene: A biologically important carotenoid for humans? Arch. Biochem. Biophys. 1996, 336, 1-9. [CrossRef]

125. Stahl, W.; Sies, H. Uptake of lycopene and its geometrical isomers is greater from heat-processed than from unprocessed tomato juice in humans. Nutr. J. 1992, 122, 2161-2166. [CrossRef]

126. Ross, A.B.; Vuong, L.T.; Ruckle, J.; Synal, H.A.; Schulze-Koenig, T.; Wertz, K.; Ruembeli, R.; Liberman, R.G.; Skipper, P.L.; Tannenbaum, S.R. Lycopene bioavailability and metabolism in humans: An accelerator mass spectrometry study. Am. J. Clin. Nutr. 2011, 93, 1263-1273. [CrossRef]

127. Kopec, R.E.; Riedl, K.M.; Harrison, E.H.; Curley Jr, R.W.; Hruszkewycz, D.P.; Clinton, S.K.; Schwartz, S.J. Identification and quantification of apo-lycopenals in fruits, vegetables, and human plasma. J. Agric. Food Chem. 2010, 58, 3290-3296. [CrossRef] 
128. Sicilia, T.; Bub, A.; Rechkemmer, G.; Kraemer, K.; Hoppe, P.P.; Kulling, S.E. Novel lycopene metabolites are detectable in plasma of preruminant calves after lycopene supplementation. Nutr. J. 2005, 135, 2616-2621. [CrossRef]

129. Cichon, M.J.; Moran, N.E.; Riedl, K.M.; Schwartz, S.J.; Clinton, S.K. Identification of an Epoxide Metabolite of Lycopene in Human Plasma Using 13C-Labeling and QTOF-MS. Metabolites 2018, 8, 24. [CrossRef] [PubMed]

130. Gajic, M.; Zaripheh, S.; Sun, F.; Erdman, J.W., Jr. Apo- $8^{\prime}$-lycopenal and apo-12'-lycopenal are metabolic products of lycopene in rat liver. Nutr. J. 2006, 136, 1552-1557. [CrossRef] [PubMed]

131. Chung, J.; Koo, K.; Lian, F.; Hu, K.Q.; Ernst, H.; Wang, X.-D. Apo-10'-lycopenoic acid, a lycopene metabolite, increases sirtuin 1 mRNA and protein levels and decreases hepatic fat accumulation in ob/ob mice. Nutr. J. 2012, 142, 405-410. [CrossRef] [PubMed]

132. Ip, B.C.; Hu, K.-Q.; Liu, C.; Smith, D.E.; Obin, M.S.; Ausman, L.M.; Wang, X.-D. Lycopene metabolite, apo-10'-lycopenoic acid, inhibits diethylnitrosamine-initiated, high fat diet-promoted hepatic inflammation and tumorigenesis in mice. Cancer Prev. Res. 2013, 6, 1304-1316. [CrossRef] [PubMed]

133. Olson, J.A. Absorption, transport and metabolism of carotenoids in humans. Pure Appl. Chem. 1994, 66, 1011-1016. [CrossRef]

134. Parker, R.S. Absorption, metabolism, and transport of carotenoids. FASEB J. 1996, 10, 542-551. [CrossRef]

135. Papachristodoulou, D.; Snape, A.; Elliott, W.H.; Elliott, D.C. Biochemistry and Molecular Biology; Oxford University Press: Oxford, UK, 2014; pp. 163-190.

136. Wang, X.-D.; Krinsky, N.I.; Marini, R.P.; Tang, G.; Yu, J.; Hurley, R.; Fox, J.G.; Russell, R.M. Intestinal uptake and lymphatic absorption of beta-carotene in ferrets: A model for human beta-carotene metabolism. Am. J. Physiol. Gastrointest. Liver Physiol. 1992, 263, 480-486. [CrossRef]

137. Eggersdorfer, M.; Wyss, A. Carotenoids in human nutrition and health. Arch. Biochem. Biophys. 2018, 652, 18-26. [CrossRef]

138. Sahni, S.; Hannan, M.T.; Blumberg, J.; Cupples, L.A.; Kiel, D.P.; Tucker, K.L. Inverse association of carotenoid intakes with 4-y change in bone mineral density in elderly men and women: The Framingham Osteoporosis Study. Am. J. Clin. Nutr. 2009, 89, 416-424. [CrossRef]

139. Sahni, S.; Hannan, M.T.; Blumberg, J.; Cupples, L.A.; Kiel, D.P.; Tucker, K.L. Protective effect of total carotenoid and lycopene intake on the risk of hip fracture: A 17-year follow-up from the Framingham Osteoporosis Study. J. Bone Miner. Res. 2009, 24, 1086-1094. [CrossRef]

140. Mackinnon, E.; Venket Rao, A.; Rao, L. Dietary restriction of lycopene for a period of one month resulted in significantly increased biomarkers of oxidative stress and bone resorption in postmenopausal women. J. Nutr. Health Aging 2011, 15, 133-138. [CrossRef] [PubMed]

141. Mackinnon, E.; Rao, A.; Josse, R.; Rao, L. Supplementation with the antioxidant lycopene significantly decreases oxidative stress parameters and the bone resorption marker N-telopeptide of type 1 collagen in postmenopausal women. Osteoporos. Int. 2011, 22, 1091-1101. [CrossRef] [PubMed]

142. Yang; Zhang; Penniston; Binkley; Tanumihardjo. Serum carotenoid concentrations in postmenopausal women from the United States with and without osteoporosis. Int. J. Vitam. Nutr. Res. 2008, 78, 105-111. [CrossRef] [PubMed]

143. Russo, C.; Ferro, Y.; Maurotti, S.; Salvati, M.A.; Mazza, E.; Pujia, R.; Terracciano, R.; Maggisano, G.; Mare, R.; Giannini, S. Lycopene and bone: An in vitro investigation and a pilot prospective clinical study. J. Transl. Med. 2020, 18, 43. [CrossRef] [PubMed]

144. Mackinnon, E.S. The Role of the Carotenoid Lycopene as an Antioxidant to Decrease Osteoporosis Risk in Women: Clinical and In Vitro Studies. Ph.D. Thesis, University of Toronto, Ontario, Canada, 2010.

145. Rao, L.; Mackinnon, E.; Josse, R.; Murray, T.; Strauss, A.; Rao, A. Lycopene consumption decreases oxidative stress and bone resorption markers in postmenopausal women. Osteoporos. Int. 2007, 18, 109-115. [CrossRef] [PubMed]

146. Calciolari, E.; Donos, N.; Mardas, N. Osteoporotic animal models of bone healing: Advantages and pitfalls. J. Invest. Surg. 2017, 30, 342-350. [CrossRef]

147. Lelovas, P.P.; Xanthos, T.T.; Thoma, S.E.; Lyritis, G.P.; Dontas, I.A. The laboratory rat as an animal model for osteoporosis research. Comp. Med. 2008, 58, 424-430.

148. Ozsahin, E.T.; Çam, B.; Dere, F.; Kurkcu, M.; Evruke, C.; Soames, R.; Oguz, O. The effect of alendronate sodium on trabecular bone structure in an osteoporotic rat model. Turk. J. Phys. Med. Rehabil. 2017, 63, 165-174. [CrossRef] 
149. Gao, X.; Ma, W.; Dong, H.; Yong, Z.; Su, R. Establishing a rapid animal model of osteoporosis with ovariectomy plus low calcium diet in rats. Int. J. Clin. Exp. Pathol. 2014, 7, 5123.

150. Thompson, D.; Simmons, H.; Pirie, C.; Ke, H. FDA Guidelines and animal models for osteoporosis. Bone 1995, 17, 125-133. [CrossRef]

151. Liang, H.; Yu, F.; Tong, Z.; Zeng, W. Lycopene effects on serum mineral elements and bone strength in rats. Molecules 2012, 17, 7093-7102. [CrossRef] [PubMed]

152. Oliveira, G.R.; Vargas-Sanchez, P.K.; Fernandes, R.R.; Ricoldi, M.S.T.; Semeghini, M.S.; Pitol, D.L.; de Sousa, L.G.; Siessere, S.; Bombonato-Prado, K.F. Lycopene influences osteoblast functional activity and prevents femur bone loss in female rats submitted to an experimental model of osteoporosis. J. Bone Miner. Metab. 2019, 37, 658-667. [CrossRef] [PubMed]

153. Li, X.; Xue, W.; Cao, Y.; Long, Y.; Xie, M. Effect of lycopene on titanium implant osseointegration in ovariectomized rats. J. Orthop. Surg. Res. 2018, 13, 237. [CrossRef] [PubMed]

154. Ishimi, Y.; Ohmura, M.; Wang, X.; Yamaguchi, M.; Ikegami, S. Inhibition by carotenoids and retinoic acid of osteoclast-like cell formation induced by bone-resorbing agents in vitro. J. Clin. Biochem. Nutr. 1999, 27, 113-122. [CrossRef]

155. Park, C.-K.; Ishimi, Y.; Ohmura, M.; Yamaguchi, M.; Ikegami, S. Vitamin A and carotenoids stimulate differentiation of mouse osteoblastic cells. J. Nutr. Sci. Vitaminol. 1997, 43, 281-296. [CrossRef]

156. Costa-Rodrigues, J.; Fernandes, M.H.; Pinho, O.; Monteiro, P.R.R. Modulation of human osteoclastogenesis and osteoblastogenesis by lycopene. J. Nutr. Biochem. 2018, 57, 26-34. [CrossRef]

157. Boyce, B.F.; Yao, Z.; Xing, L. Functions of NF-кB in Bone. Ann. N. Y. Acad. Sci. 2010, 1192, 367. [CrossRef]

158. Linnewiel-Hermoni, K.; Motro, Y.; Miller, Y.; Levy, J.; Sharoni, Y. Carotenoid derivatives inhibit nuclear factor kappa B activity in bone and cancer cells by targeting key thiol groups. Free Radic. Biol. Med. 2014, 75, 105-120. [CrossRef]

159. Marcotorchino, J.; Romier, B.; Gouranton, E.; Riollet, C.; Gleize, B.; Malezet-Desmoulins, C.; Landrier, J.F. Lycopene attenuates LPS-induced TNF- $\alpha$ secretion in macrophages and inflammatory markers in adipocytes exposed to macrophage-conditioned media. Mol. Nutr. Food Res. 2012, 56, 725-732. [CrossRef]

160. Feng, D.; Ling, W.-H.; Duan, R.-D. Lycopene suppresses LPS-induced NO and IL-6 production by inhibiting the activation of ERK, p38MAPK, and NF-kB in macrophages. Inflamm. Res. 2010, 59, 115-121. [CrossRef]

161. De Stefano, D.; Maiuri, M.C.; Simeon, V.; Grassia, G.; Soscia, A.; Cinelli, M.P.; Carnuccio, R. Lycopene, quercetin and tyrosol prevent macrophage activation induced by gliadin and IFN- $\gamma$. Eur. J. Pharmacol. 2007, 566, 192-199. [CrossRef] [PubMed] 